\title{
An overview of two years of ozone radio soundings over Cotonou as part of AMMA
}

\author{
V. Thouret ${ }^{1,2}$, M. Saunois ${ }^{1,2}$, A. Minga ${ }^{3}$, A. Mariscal ${ }^{1,2, *}$, B. Sauvage ${ }^{1,2}$, A. Solete ${ }^{4}$, D. Agbangla ${ }^{4}$, P. Nédélec ${ }^{1,2}$, \\ C. Mari ${ }^{1,2}$, C. E. Reeves ${ }^{5}$, and H. Schlager ${ }^{6}$ \\ ${ }^{1}$ Université de Toulouse, UPS, LA (Laboratoire d'Aérologie), 14 avenue Edouard Belin, 31400, Toulouse, France \\ ${ }^{2}$ CNRS, LA (Laboratoire d'Aérologie), 31400 Toulouse, France \\ ${ }^{3}$ Faculté des Sciences, Université Marien NGouabi, BP 2702 Brazzaville, Congo \\ ${ }^{4}$ Agence pour la SECurité de la Navigation Aérienne en Afrique et à Madagascar (ASECNA), BP 96, Cotonou, Benin \\ ${ }^{5}$ School of Environmental Sciences, University of East Anglia, Norwich, NR4 7TJ, UK \\ ${ }^{6}$ Deutsches Zentrum fuer Luft-und Raumfahrt (DLR), Institut fuer Physik der Atmosphaere, Oberpfaffenhofen, \\ 82234 Wessling, Germany \\ "now at: LGIT (Laboratoire de Géophysique Interne et Technophysique), BP 53, 38041 Grenoble, Cedex 09, France
}

Received: 8 April 2009 - Published in Atmos. Chem. Phys. Discuss.: 5 May 2009

Revised: 22 July 2009 - Accepted: 6 August 2009 - Published: 28 August 2009

\begin{abstract}
As part of the African Monsoon Multidisciplinary Analysis (AMMA) program, a total of 98 ozone vertical profiles over Cotonou, Benin, have been measured during a 26 month period (December 2004-January 2007). These regular measurements broadly document the seasonal and interannual variability of ozone in both the troposphere and the lower stratosphere over West Africa for the first time. This data set is complementary to the MOZAIC observations made from Lagos between 0 and $12 \mathrm{~km}$ during the period 1998-2004. Both data sets highlight the unique way in which West Africa is impacted by two biomass burning seasons: in December-February (dry season) due to burning in the Sahelian band and in June-August (wet season) due to burning in southern Africa. High interannual variabilities between Cotonou and Lagos data sets and within each data set are observed and are found to be a major characteristic of this region. In particular, the dry and wet seasons are discussed in order to set the data of the Special Observing Periods (SOPs) into a climatological context. Compared to other dry and wet seasons, the 2006 dry and wet season campaigns took place in rather high ozone environments. During the sampled wet seasons, southern intrusions of biomass burning were particularly frequent with concentrations up to $120 \mathrm{ppbv}$ of ozone in the lower troposphere. An insight into the ozone distribution in the upper troposphere and the lower stratosphere (up to $26 \mathrm{~km}$ ) is given. The first tropospheric columns of ozone
\end{abstract}

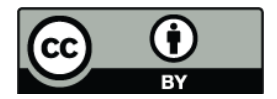

Correspondence to: V. Thouret (valerie.thouret@aero.obs-mip.fr) based on in-situ data over West Africa are assessed. They compare well with satellite products on seasonal and interannual time-scales, provided that the layer below $850 \mathrm{hPa}$ where the remote instrument is less sensitive to ozone, is removed.

\section{Introduction}

Tropospheric ozone is an important trace gas in particular via its role in the oxidative capacity of the global atmosphere and its climate effect. Two main reasons make the tropical regions of interest regarding tropospheric ozone. Firstly photochemistry and $\mathrm{OH}$ formation are more active in the tropics due to high UV radiation and humidity. Secondly, the tropics are important source regions of ozone precursors especially through biomass burning (Andreae and Merlet, 2001; van der Werf et al., 2006), biogenic (Guenther et al., 1995; Serça et al., 1998; Jaeglé et al., 2004, 2005; Guenther et al., 2006; Aghedo et al., 2007) and lightning emissions (Moxim and Levy, 2000; Sauvage et al., 2007b; Höller et al., 2009).

The previous African campaigns (from TROPOZ 1987 to TRACE-A and SAFARI 2000) have effectively highlighted the importance of the tropical region, and particularly Africa, as a source region of ozone precursors (e.g., Cros et al., 1992, 2000; Delmas et al., 1999; Jonquière et al., 1998; Jacob et al., 1996; Pickering et al., 1996; Swap et al., 2003). Most of the data obtained during those campaigns come from low spatial or temporal sampling, meaning that regional and/or seasonal, annual or interannual variabilities are not well documented.

Published by Copernicus Publications on behalf of the European Geosciences Union. 


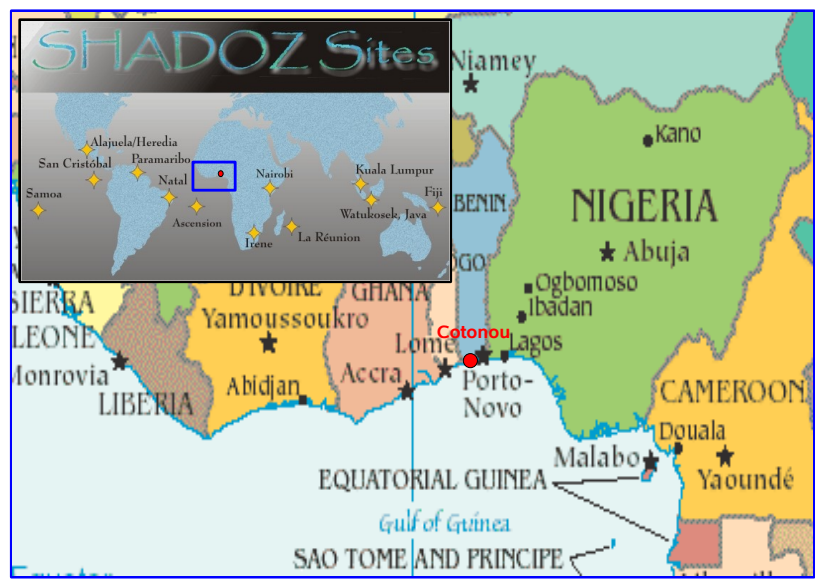

Fig. 1. Map of West Africa. The experimental site of Cotonou, Benin is represented by the red dot, $110 \mathrm{~km}$ west of Lagos, Nigeria. A map of the SHADOZ sites as visible on the web site http://croc. gsfc.nasa.gov/shadoz/ is presented as well showing that Cotonou fills an empty place within the SHADOZ network.

More recently, the only data set providing regular ozone profiles over West Africa has come from the MOZAIC program (Marenco et al. (1998) and http://mozaic.aero.obs-mip. fr/web/). This program recorded ozone concentrations over Abidjan, Ivory Coast and Lagos, Nigeria from 1998 to the beginning of 2004, with most of the data in 2000 and 2003. Thus the first climatology of tropospheric ozone over West Africa up to $200 \mathrm{hPa}(12 \mathrm{~km})$ was established by Sauvage et al. (2005). In particular, they showed that the ozone distribution over West Africa is influenced by two biomass burning seasons, in December to February (DJF) due to fires in the Sahelian area and in June to August (JJA) due to fires in the northern part of the southern hemisphere. Further details can be found in the following studies: Sauvage et al. (2006, 2007b,c). Previously, the complexity of the ozone distribution in this region (equatorial Atlantic and adjacent continents) was highlighted by the analysis of Thompson et al. (2000); Martin et al. (2002); Edwards et al. (2003); Jenkins and Ryu (2004) based on satellite data or in-situ data during a cruise between the East coast of the US and South Africa.

As part of the African Monsoon Multidisciplinary Analysis (AMMA) program, which aims in particular to document the chemical composition of the West African atmosphere and its variations linked to dynamics and climate, an ozone sounding station was set up in Cotonou, Benin $\left(6.21^{\circ} \mathrm{N}, 2.23^{\circ} \mathrm{E}\right)$ (Fig. 1) thanks to the IRD (Institut de Recherche et Développement) and the SMN/ASECNA (Service Météorologique National/Agence de securité et de navigation aérienne) people located there. These regular soundings were performed during the Enhanced Observation Period (EOP) in 2005-2006 and aimed to better assess the seasonal and interannual variability of ozone vertical profiles in Equatorial Africa.

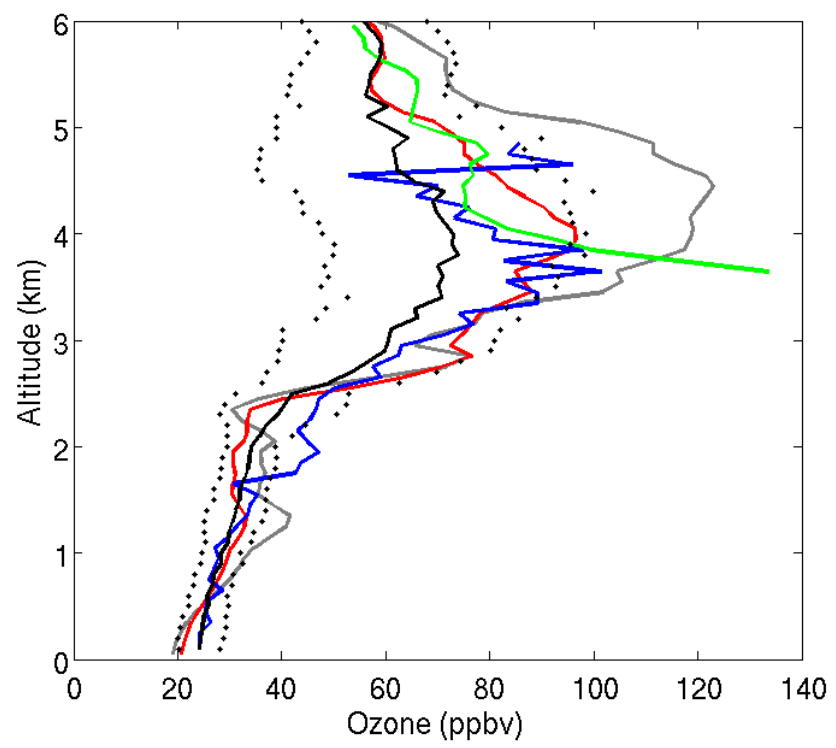

Fig. 2. Vertical profiles of ozone up to $6 \mathrm{~km}$ from the RS data set: August monthly mean (black solid line) and standard deviation (black dots), average of the two soundings on 10 and 14/08 (red solid line), sounding on 14/08 (grey solid line); from BAe-146 in the region between $5.5^{\circ} \mathrm{N}$ and $7^{\circ} \mathrm{N}$ on the 08 and 13/08 (dark blue solid line); and from D-F20 in the region $4-5.5^{\circ} \mathrm{N}$ on the $13 / 08$ (green solid line)

This new data set supplies complementary and additional knowledge regarding the ozone vertical distribution in the tropics and in particular in West Africa where ozonesondes were launched for the first time. The uses of such a data set range from ozone distribution studies (its main features and variations related to dynamics and climate), remote sensing satellite validation (in particular the tropospheric ozone column) to validation of chemistry-transport models used to interpret observations from various platforms (satellite, airborne, in-situ). The objectives of this paper are the following:

1. present the entire data set from December 2004 to January 2007, including the evaluation against aircraft measurements during the campaign in summer 2006 and against the MOZAIC climatology (Sect. 2)

2. detail the measurements performed during the Special Observing Periods (SOPs) during the dry and wet seasons of 2006 (December-February and June-August respectively) and set these data into a climatological context (Section 3).

3. highlight new features identified in this data set. In particular, we will characterize the UTLS (Upper Troposphere/Lower Stratosphere - above $200 \mathrm{hPa}$ ) that has not been sampled previously (Sect. 4). In Sect. 5, we will give a first assessment of the tropospheric columns over West Africa based on the in-situ data. 
Table 1. Number of ozone soundings recorded over Cotonou during AMMA.

\begin{tabular}{|c|c|c|c|c|c|c|c|c|c|c|c|c|}
\hline & January & February & March & April & May & June & July & August & September & October & November & December \\
\hline 2004 & & & & & & & & & & & & 2 \\
\hline 2005 & 2 & 4 & 2 & 4 & 3 & 4 & 0 & 3 & 3 & 5 & 4 & 3 \\
\hline 2006 & 5 & 3 & 4 & 3 & 4 & 9 & 8 & 7 & 3 & 3 & 3 & 1 \\
\hline 2007 & 6 & & & & & & & & & & & \\
\hline
\end{tabular}

\section{Data presentation and evaluation in the lower and mid troposphere}

\subsection{Data acquisition}

Regular weekly measurements were performed from December 2004 to January 2007. This frequency was doubled during the SOPs in January 2006 and July-August 2006 to provide better statistics during the dry and wet seasons. A total of 98 profiles are now archived and available in the AMMA data base (http://database.amma-international.org/), on the SHADOZ archive (Southern Hemisphere Additional Ozonesondes; http://croc.gsfc.nasa.gov/shadoz/ and Thompson et al. (2003a,b)) and in the WOUDC archive (World Ozone Data Center sponsored by the World Meteorological Organization (WMO); http://www.woudc.org) as well. Table 1 gives the number of profiles for each month. Due to serious technical problems in July 2005, January 2006 and December 2006, we were not able to perform as many soundings as scheduled.

The ozone measurements were made with balloon-borne ECC (Electrochemical Concentration Cell) ozonesondes coupled with a standard radiosonde including a sensor for relative humidity and temperature. We used the Vaisala manufactured RS80 radiosondes during the entire AMMA period. The air for the ozone measurements was sampled with a Science Pump 6A type. Briefly, the principle of an ECC sensor is the following. A potential difference is set up between two cells (anode and cathode) with different strengths of KI (potassium iodide) solution (Komhyr, 1967). Then, the amount of ozone present in the sampled air is given by a formula including the current developed due to electrochemical reactions, the current relative to a zero-ozone background value, the temperature of the pump, the flow rate, and a correction factor accounting for the response time of the solution and the slowdown in the efficiency of the ozonesonde pump at high altitude and low temperature. All these terms are sources of uncertainties. It has long been recognized that the pump efficiency correction is the greatest source of uncertainty in the profile as a whole (Komhyr, 1986; DeBacker et al., 1998). Similar to the SHADOZ data (Thompson et al., 2003a), no correction factors from a co-located total ozone instrument have been applied to these AMMA soundings data. The overall uncertainties in the ozone soundings measurements have been evaluated to be in the range $4-12 \%$ for the ECC sondes (Barnes et al., 1985; Beekmann et al., 1994; Komhyr et al., 1995). As part of the SHADOZ programme (tropical area), Thompson et al. (2003a) have shown an ozonesonde precision of 5\% when compared to independent Dobson instruments. More recently, sonde intercomparisons experiments have been conducted, as a WMO sponsored work, in simulation chamber (Smit et al., 2007) or in balloon flight (Deshler et al., 2008) for looking at data quality critically. They finally showed that standardization of operating procedures for ECC-sondes yields a precision better than $\pm(3-5) \%$ and an accuracy of about $\pm(5-10) \%$ up to $30 \mathrm{~km}$ altitude. Thompson et al. (2007) have also evaluated the SHADOZ data with simulated flight profiles. Smit et al. (2007) also showed that the best agreement with UVphotometer was found with ECC-SP sondes types using a $1.0 \%$ buffered solution, which is that used in Cotonou. When compared to UV analysers onboard commercial aircrafts, Thouret et al. (1998) have shown that mean concentrations derived from ozonesondes are about 3 to $13 \%$ higher than those obtained by the MOZAIC program in the free troposphere in a similar geographic location.

\subsection{Comparison with aircraft data in August 2006}

It is well recognized that ozone soundings are quite difficult to operate. Many sources of errors can be attributed to the sonde preparation 4 to 7 days in advance, to the storage of the sondes and electrochemical solutions and to the balloon preparation just before launching. These errors are particularly sensitive to tropical conditions due to high temperature and humidity. There is no easy way to check the data quality and consistency. Each ozonesonde launched is a new instrument. During the AMMA SOPs, ozone measurements were also made onboard research aircraft using UV photometers. Characteristics of the instruments (accuracies, detection limits) are summarized in Reeves et al. (2009). Unfortunately we did not have the opportunity to coordinate a sounding with the take off or landing from Cotonou airport of one of the aircraft measuring ozone. A good agreement between the average vertical profiles of ozone from aircraft data around $6^{\circ} \mathrm{N}$ and those from the radiosoundings over Cotonou during July and August 2006 has been found by Reeves et al. (2009). However, they note the soundings data are higher than the aircraft data in the upper troposphere (between 550 and $150 \mathrm{hPa}$ ) due to the difference in measurement technique 


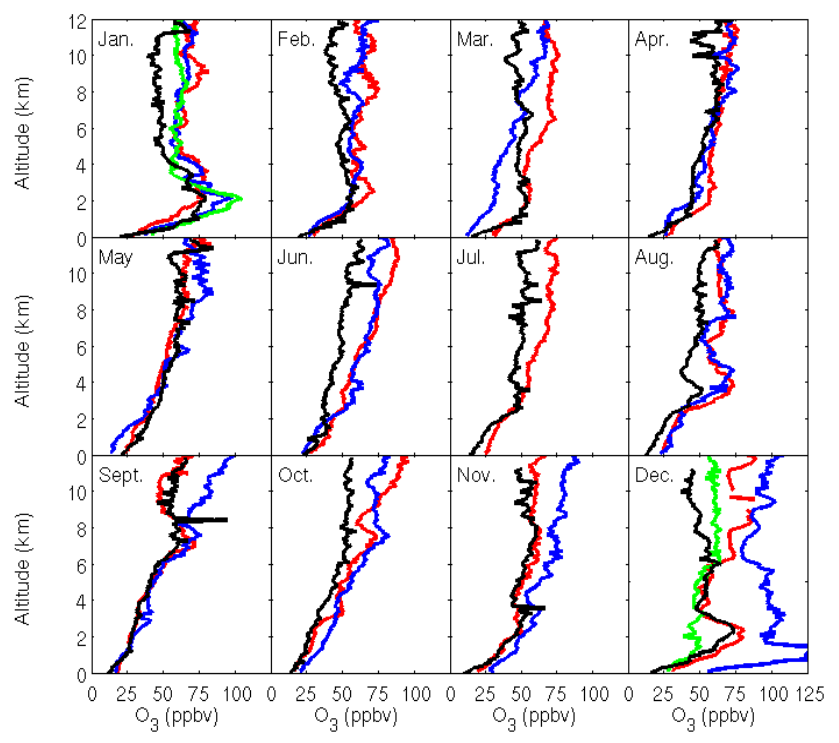

Fig. 3. Monthy mean vertical profiles of $\mathrm{O}_{3}$ from the Cotonou RS (December 2004 and January 2007: green, 2005: blue and 2006: red) and from the MOZAIC climatology (black) over Lagos $\left(1^{\circ} \mathrm{E}\right.$ from Cotonou) from the surface to $12 \mathrm{~km}$.

but also, in part, to the strategy of operations. Balloons were launched every 3 to 4 days regardless of meteorological conditions while some aircraft flights in the upper troposphere were dedicated to the analyses of the mesoscale convective system outflows (explaining the relatively low ozone concentrations in the UT). The July-August 2006 mean profiles measured from both the ozonesondes and aircraft show an ozone enhancement in the lower troposphere characteristic of the biomass burning plumes from the southern hemisphere as detailed in Sauvage et al. (2005, 2007a) and Mari et al. (2008). Reeves et al. (2009) show that on average, the ozone radiosoundings data exhibit lower concentrations than the aircraft data in the lower troposphere (around 3-4 km) and suggest that a greater amount of air sampled by the aircraft had been influenced by biomass burning.

A thorough comparison between soundings and aircraft data is made in Fig. 2 for a shorter period (8-14 August 2006). This period is characterized by the so-called "extreme event" recorded on 14 August 2006 when the highest ozone concentrations (120 ppbv) were measured over Cotonou (Fig. 2, grey line). Figure 2 presents the mean vertical profiles between the surface and up to $6 \mathrm{~km}$ recorded by the soundings on the 10th and 14th, the BAe-146 aircraft on the 8 th and 13 th between $5.5-7^{\circ} \mathrm{N}$ and the D-F20 aircraft on the 13 th around $4-5.5^{\circ} \mathrm{N}$. They all show maxima from 80 to more than $130 \mathrm{ppbv}$ between 3 and $5 \mathrm{~km}$, well above the seasonal average (black line). The mean ozone profile from the BAe data (dark blue line) shows good agreement with the ozonesonde data regarding the altitude and magnitude of the enhancement. The two data sets also well agree in the lower

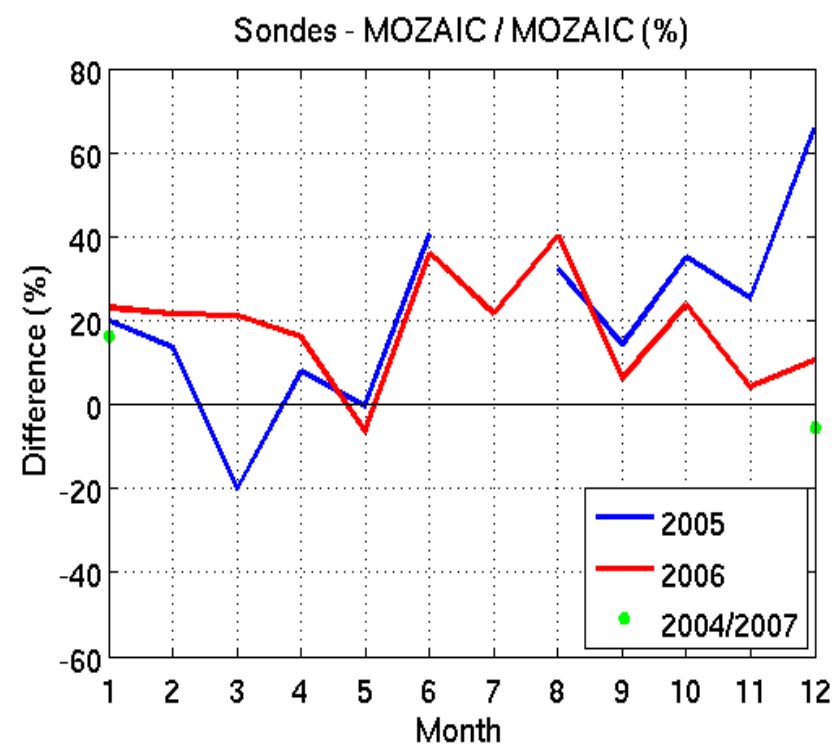

Fig. 4. Differences calculated between Cotonou RS and MOZAIC climatology over Lagos between 2 and $8 \mathrm{~km}$ for December 2004, years 2005 and 2006 and January 2007.

troposphere. On the 13th the D-F20 (green line) sampled a biomass burning pollution plume located below $5 \mathrm{~km}$ with highly enhanced concentrations of ozone and ozone precursors (Andrès-Hernández et al., 2009). The ozone maximum sampled by the D-F20 is higher and at lower altitude probably because it has been sampled further south and further west. However, the top of the enhanced ozone layer is very similar to that observed from soundings.

\subsection{Comparison with the MOZAIC climatology}

An objective for this new data set is to be a reference for the ozone distribution throughout the troposphere and the lower stratosphere over West Africa. Therefore, it is necessary to assess how well this AMMA data set agrees with the MOZAIC climatology over Lagos presented by Sauvage et al. (2005). Lagos is situated $110 \mathrm{~km}$ east of Cotonou, also by the Gulf of Guinea coast (Fig. 1) and we expect similar seasonal characteristics at least above the boundary layer. Equipped MOZAIC aircraft started collecting data en-route to Lagos in 1998, but unfortunately stopped their regular operation there in March 2004 before the start of the AMMA soundings (December 2004). No direct comparison is therefore possible to evaluate any bias between the two measurement techniques.

Figure 3 presents the monthly mean vertical profiles of ozone over Lagos for the MOZAIC climatology and over Cotonou for the 26 month period (both averaged every $100 \mathrm{~m}$ ). As expected, both data sets show similar seasonal variations. In particular, both are marked with ozone enhancements around $2-3 \mathrm{~km}$ in the Harmattan layer during 


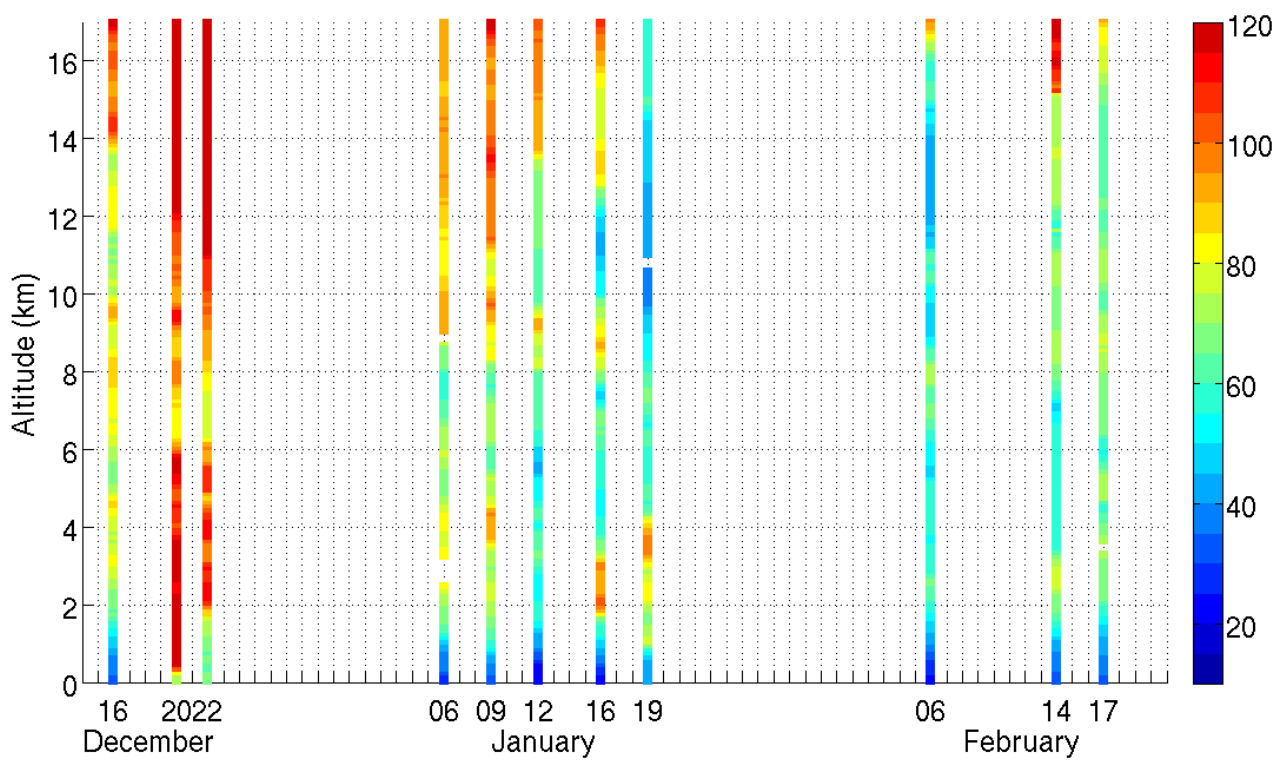

Fig. 5. Time series of the ozone profiles from the surface up to $17 \mathrm{~km}$ during December-January-February 2005/2006.

(a)

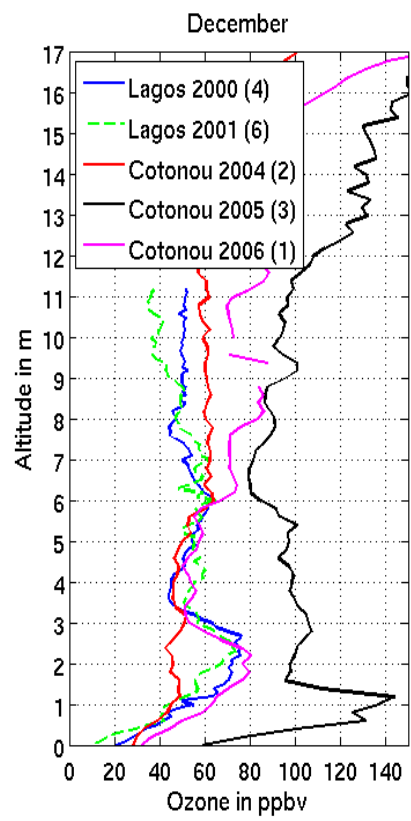

(b)

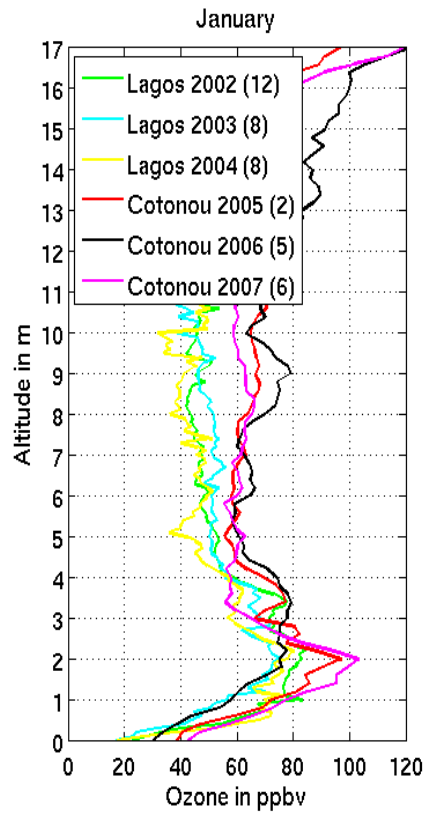

(c)

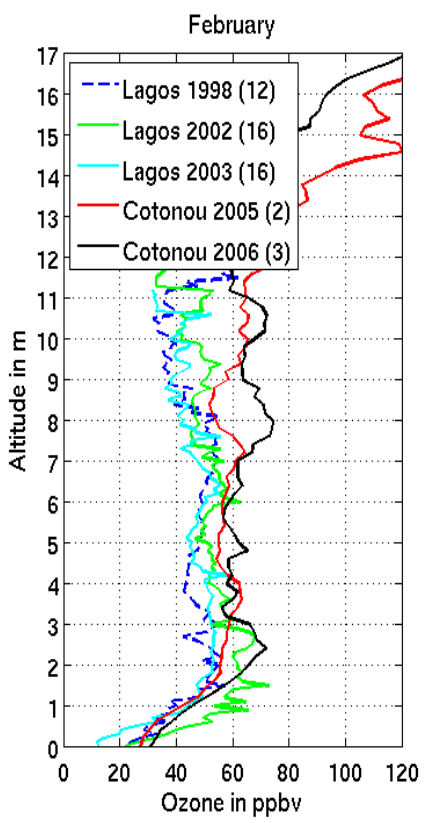

Fig. 6. Monthly mean ozone profiles over Lagos and Cotonou in December (a), January (b) and February (c). Colour Code for Cotonou RS: dry season 2004-2005 (red), 2005-2006 (black), 2006-2007 (pink).

the dry season (December-January-February) and around 3$4 \mathrm{~km}$ during the wet season (June-July-August) due to fires in the Sahelian region and in the northern part of the Southern Hemisphere, respectively. However, it seems that the soundings data show higher concentrations than the MOZAIC data in the middle and upper troposphere (e.g. see JJA, DJF, as well as October). Indeed, Thouret et al. (1998) have shown that there can be up to $13 \%$ difference between the ozonesondes and MOZAIC data. However, this overestimation does not seem to be global or systematic. In April and May, soundings and aircraft data show only small differences. For instance, September and November 2006 exhibit profiles 
close to the MOZAIC average whereas large differences relative to the MOZAIC climatology appear in the mid and upper troposphere in 2005. Conversely, the January profiles from soundings are similar to each other and high compared to MOZAIC. In December, all four profiles show very different ozone levels above $6 \mathrm{~km}$.

To further quantify this variability, Fig. 4 gives the difference (\%) between MOZAIC (taken as the reference) and the sonde data for the layer $2-8 \mathrm{~km}$ and for the 3 years of sampling. This is the layer where the comparison is probably the most relevant because the local surface effects (different urban pollution and time of sampling) do not have a significant influence and the locations of the different measurements are in the range of one to two hundred $\mathrm{km}$. In general, the highest differences relatively to MOZAIC are observed in JJA, DJF and October. In JJA, the sounding profiles are similar while the MOZAIC distributions were more variable (Figs. 3 and 9 which is detailed in Sect. 3.2 and presents MOZAIC and AMMA monthly means for each sampled wet season). However, in December, the differences range from 7 to $60 \%$ as also seen in Fig. 6 (which is detailed in Sect. 3.1 and presents MOZAIC and AMMA monthly means for each sampled dry season). This difference is noticeable throughout the troposphere. For the annual average, the difference is $20 \%$ (sondes higher than MOZAIC) which is higher than the range of uncertainties of the measurements. As there is no overlap in the sampling periods, we cannot conclude on differences or bias between instruments. Given that the strongest differences are seen in DJF and JJA when ozone maximize in the lower troposphere, the interannual variabilities of the processes leading to ozone enhancements (emission and transport of biomass burning products) may explain most of these $20 \%$.

\section{Measurements during the Special Observation Peri- ods}

One of the objectives of the EOP measurements was to give a more general and regional context for the data from the SOPs. The following sub-sections focus on the dry and the wet seasons for which SOPs were carried out in 2006.

\subsection{Climatological context for the 2005-2006 dry season DJF}

The first SOP, SOP-0, took place in January 2006 (Haywood et al., 2008). It mainly focused on the measurement of aerosols originating from Saharan dust and biomass burning as detailed in Mallet et al. (2008) and Raut and Chazette (2008). The individual soundings measured during the dry season 2005-2006 are presented in Fig. 5 as a time series. The highest values recorded during this period were on 20 and 22 December 2005 notably in the lower troposphere but also for the entire tropospheric column. In addition to the very high ozone concentrations measured above $2 \mathrm{~km}$, extreme ozone values were recorded around $1 \mathrm{~km}$ on 20 December (Fig. 5) (Minga et al., 2009). Biomass burning signatures are clearly observed in each profile in January at $3-4 \mathrm{~km}$ in the Harmattan layer. High ozone concentrations were also measured near 8-10 km in January 2006. These ozone enhanced layers probably originate from biomass burning products lifted by convection as previously described in the frame of TRACE-A by Pickering et al. (1996). Within AMMA, Mari et al. (2008) described such processes during the wet season. Although these processes are similar, they are symmetrical in that they occur in opposing hemispheres and seasons. Pollutants emitted by fires in the southern (northern) hemisphere during the wet (dry) season are trapped over the continent and advected to the north (south) by the trade winds (Harmattan flow) where they reach convective regions located further north (south) of the fire regions and are injected in the upper troposphere. A further study should be dedicated to better analyse these signatures and draw symmetrical schemes of the processes involved during the dry and the wet seasons. In February, the profiles are more homogeneous vertically with lower values in the lower troposphere.

Figure 6 compares the monthly mean of ozone vertical profiles over Cotonou recorded during the months of December, January and February between 2004 and 2007, with the MOZAIC measurements taken over Lagos in 2002, 2003 and 2004. In January, average concentrations in the Harmattan layer $(1-3 \mathrm{~km})$ almost reach $80 \mathrm{ppbv}$. This is quite similar to that observed over Lagos in 2002, 2003 and 2004. However, MOZAIC aircraft measured more ozone in the lower part of the Harmattan layer in 2002 than the soundings in 2006. Concentrations over Lagos reach $84 \mathrm{ppb}$ at $2.2 \mathrm{~km}$ and are greater than $70 \mathrm{ppb}$ between 1 and $3.6 \mathrm{~km}$ altitude this month. On the other hand soundings in 2005 and 2007 show average concentrations as high as $100 \mathrm{ppb}$ at $2 \mathrm{~km}$ altitude. Within the AMMA data set, overall 2006 shows the highest values above $4 \mathrm{~km}$. This is consistent with December 2005 showing very high ozone concentrations from the ground to the lower stratosphere compared to 2004 and 2006 (Fig. 6a). Indeed, individual soundings from the beginning of January $(6,9,12)$ show higher concentrations than those from the end of the month $(16,19)$ especially in the upper troposphere (Fig. 5). In general, this dry season DJF 2005-2006 presents higher ozone concentrations which is consistent with higher concentrations of black carbon from biomass burning in 2005 compared to 2006 (C. Liousse, personal communication).

\subsection{Climatological context for the wet season JJA 2006}

The third SOP, SOP-2, took place in July and August 2006 with various chemical objectives described by Janicot et al. (2008) and a large aircraft operation between Niamey, Niger and the Gulf of Guinea. The chemical characterization of the troposphere over West Africa during this period is widely described by Reeves et al. (2009). Other aircraft data regarding 


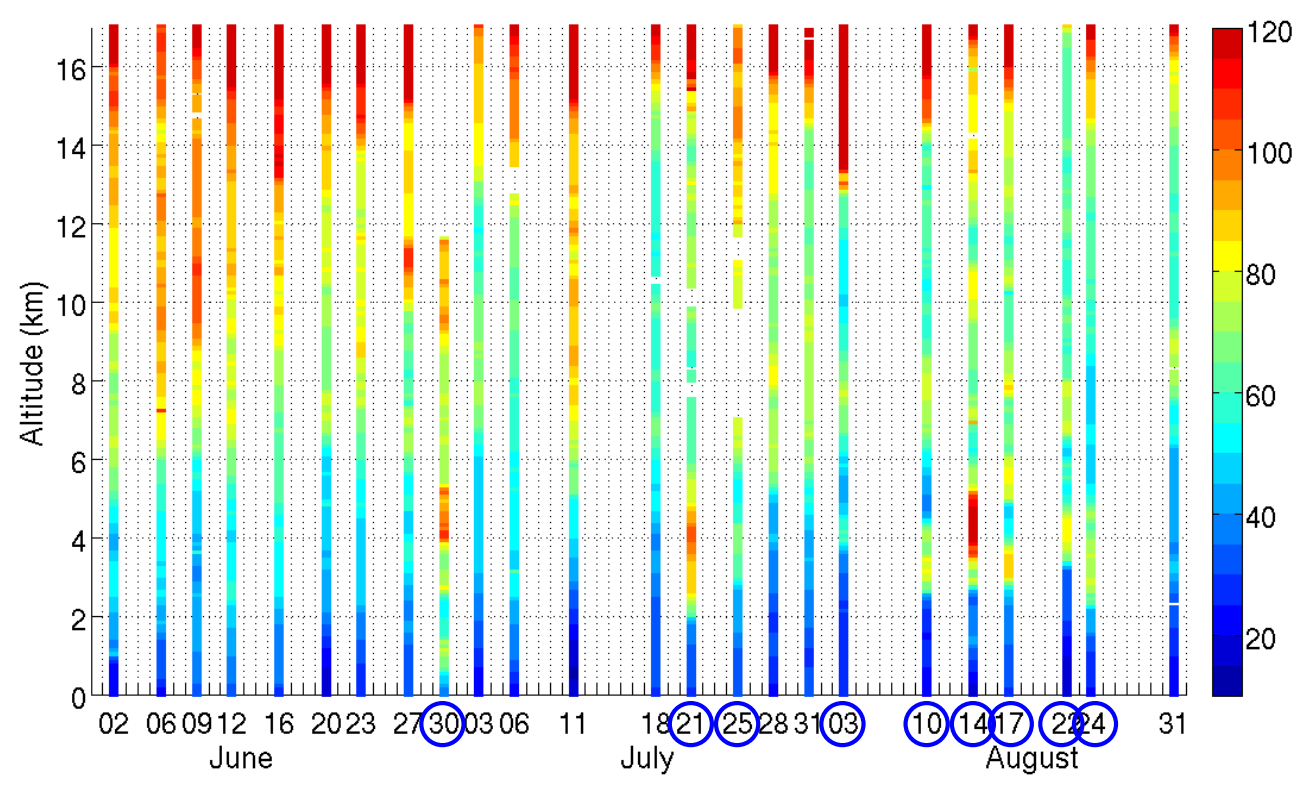

Fig. 7. Time series of the ozone profiles from the surface up to $17 \mathrm{~km}$ during June-July-August 2006. Dates with $\mathrm{O}_{3}$ enhancement are circled.

(a)
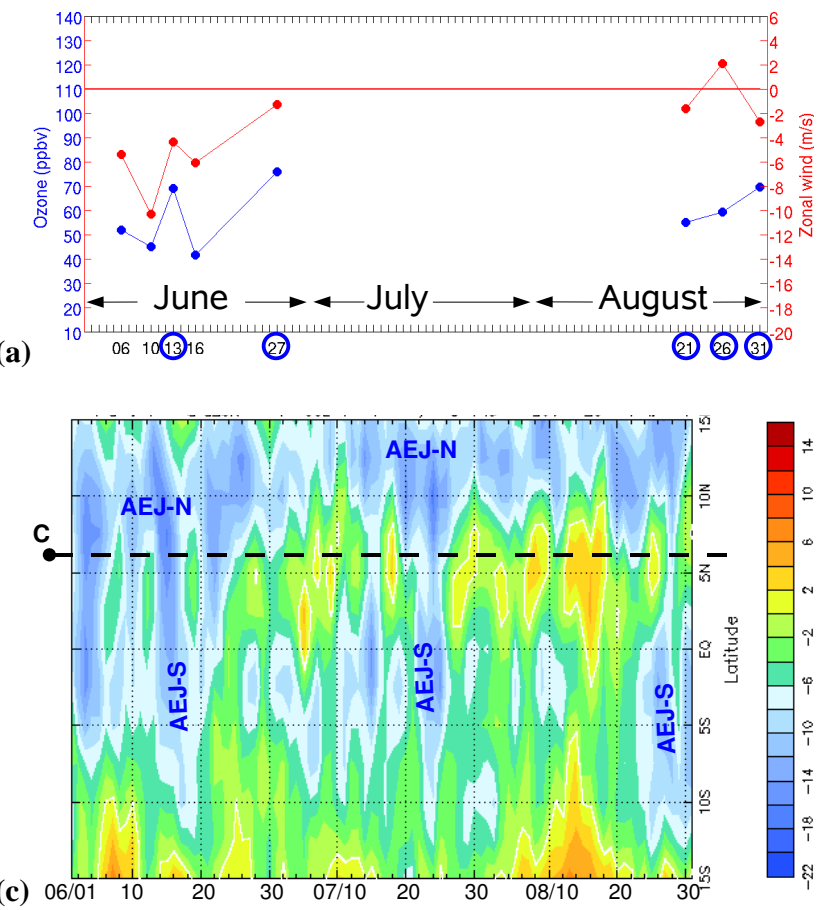

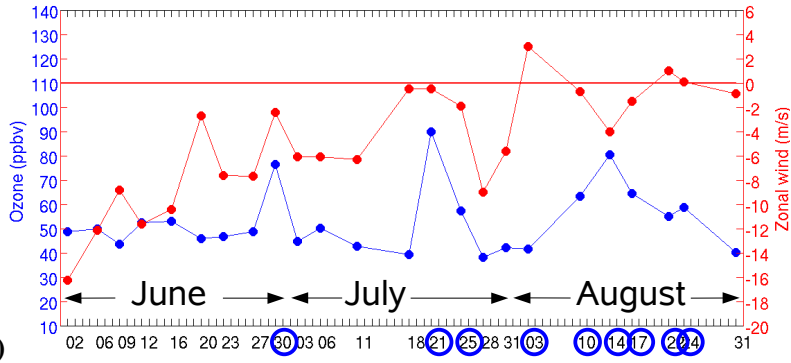

(b) (d)

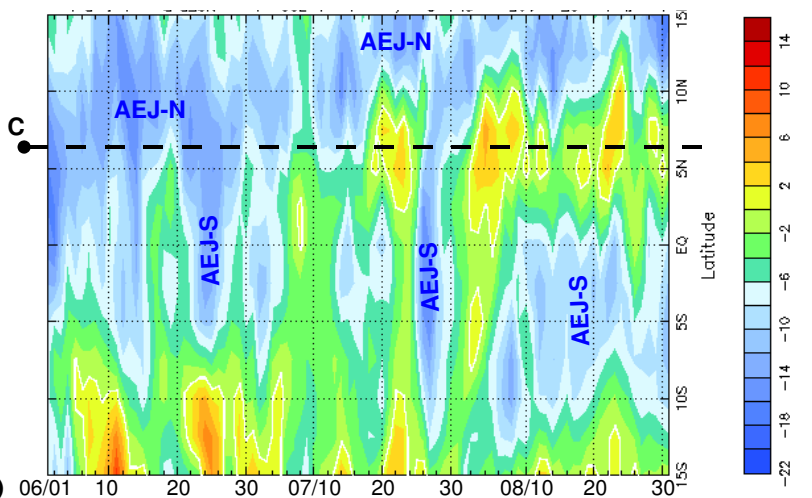

Fig. 8. Time series during the period June-July-August 2005 (a) and June-July-August 2006 (b) of the mean ozone concentration (blue) and zonal wind speed (red) as measured by radiosounding and averaged between 600 and $800 \mathrm{hPa}$. Date with $\mathrm{O}_{3}$ enhancement are circled. Bottom panel: time-latitude diagram of the mean zonal wind speed in $\mathrm{m} \mathrm{s}^{-1}$ between $0^{\circ} \mathrm{E}$ and $10^{\circ} \mathrm{E}$ from NCEP reanalysis at $700 \mathrm{hPa}$ for June-July-August 2005 (c) and June-July-August 2006 (d). The dark line corresponds to the latitude of Cotonou. 
(a)

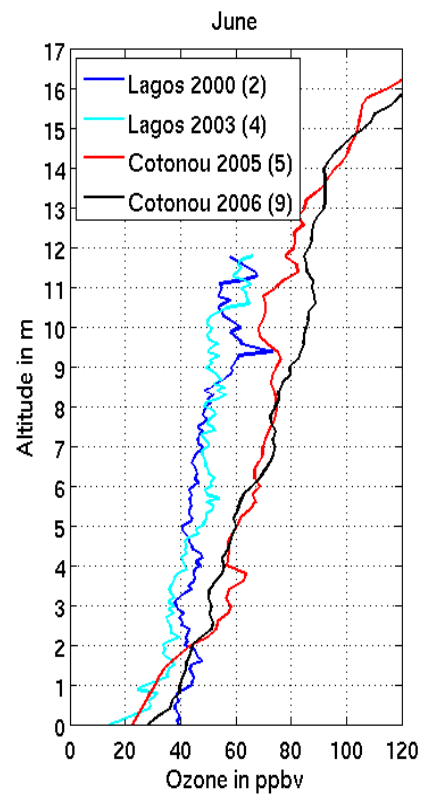

(b)

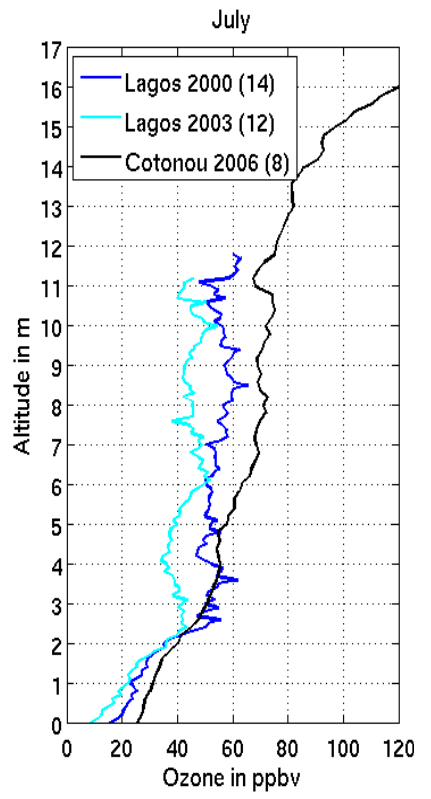

(c)

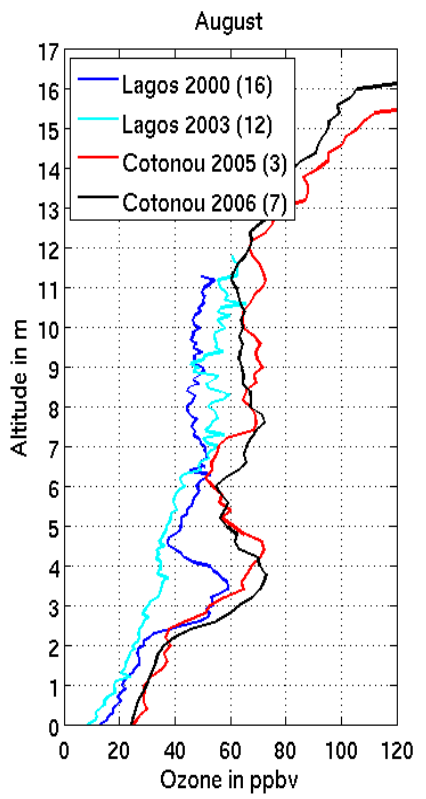

Fig. 9. Monthly mean ozone profiles over Lagos (2000: dark blue and 2003: light blue) and Cotonou (2005: black and 2006: red) in June (a), July (b) and August (c).

the influence of convection on the chemical composition are presented by Ancellet et al. (2009) and Andrès-Hernández et al. (2009). Figure 7 presents the 24 vertical profiles recorded in JJA 2006. In contrast to the dry season DJF, the vertical gradient of ozone is more pronounced. This period is characterized by ozone enhanced layers between 3 and $5 \mathrm{~km}$ attributed to southern biomass burning products (see Sect. 2.2) and profiles with such ozone layers correspond to the dates circled. These southern intrusions were rare in June (only the 30th) and July (2 on 8) whilst they were nearly a daily occurrence during August 2006. Ozone concentrations in the upper troposphere are higher in June and in the beginning of July compared to August. We have characterized the SOP-2 by the "extreme event" (Sect. 2.2, Fig. 2) when up to $120 \mathrm{ppb}$ were measured at $4 \mathrm{~km}$ on 14 August. Figure 8 has been designed to highlight the intra seasonal variability and the relationship between the ozone concentrations and the meteorological conditions in the layer 600$800 \mathrm{hPa}$. For each sounding in JJA 2005 and 2006, the ozone concentrations and the zonal wind speed have been averaged between 600 and $800 \mathrm{hPa}$ (Fig. 8a and b). The ozone background value at this pressure is around $40-50$ ppbv. Days without intrusions generally show strong easterly zonal wind $\left(<-5 \mathrm{~m} \mathrm{~s}^{-1}\right)$ attributed to the northern African Easterly Jet (AEJ-N) while days with intrusions are characterized by weak zonal wind speed, the AEJ-N being further north. Figure $8 \mathrm{c}$ and $8 \mathrm{~d}$ give the temporal variation of the zonal wind at the logitude of Cotonou during JJA 2005 and 2006 respectively from NCEP reanalysis. A good agreement is found be- tween in-situ observations and NCEP reanalysis zonal wind speed, especially regarding temporal variations during the JJA period. When Cotonou is under the influence of the AEJ$\mathrm{N}$, the jet prevents biomass burning intrusions going further north ("blocking effect"). Mari et al. (2008) have already suggested that the intra seasonal variability of the biomass burning intrusions is related to the activity of the AEJ-S (located at $\sim 5^{\circ} \mathrm{S}$, latitude of the fires regions). Indeed, most of days with intrusions have been preceded by days characterized by strong easterly winds at $2.5-5^{\circ} \mathrm{S}$ (AEJ-S). This jet allows an efficient transport of pollutants over the ocean and the Gulf of Guinea. The same analysis has been done for JJA 2005 with 5 out of 8 profiles showing biomass burning signatures (Fig. 8b). The zonal wind is much more variable during the 2005 wet season and the AEJ-S is not well pronounced for long periods (as in August 2006 for instance). As for 2006, days with intrusions show weak zonal wind. However, it is difficult to see if all these days were preceded by a strong transport by the AEJ-S over the ocean. Nevertheless, these two figures highlight the strong intra-seasonal and interannual variability regarding wind patterns and ozone concentrations in this region. They suggest that intrusions are favoured by an AEJ-N located north of Cotonou and possibly by an active AEJ-S over the fires region in the southern hemisphere. However, other processes are still to be investigated to completely explain these southern intrusions. At the monthly mean scale, different dynamical situations in August 2005 and 2006 can lead to similar ozone vertical profiles as discussed below. 


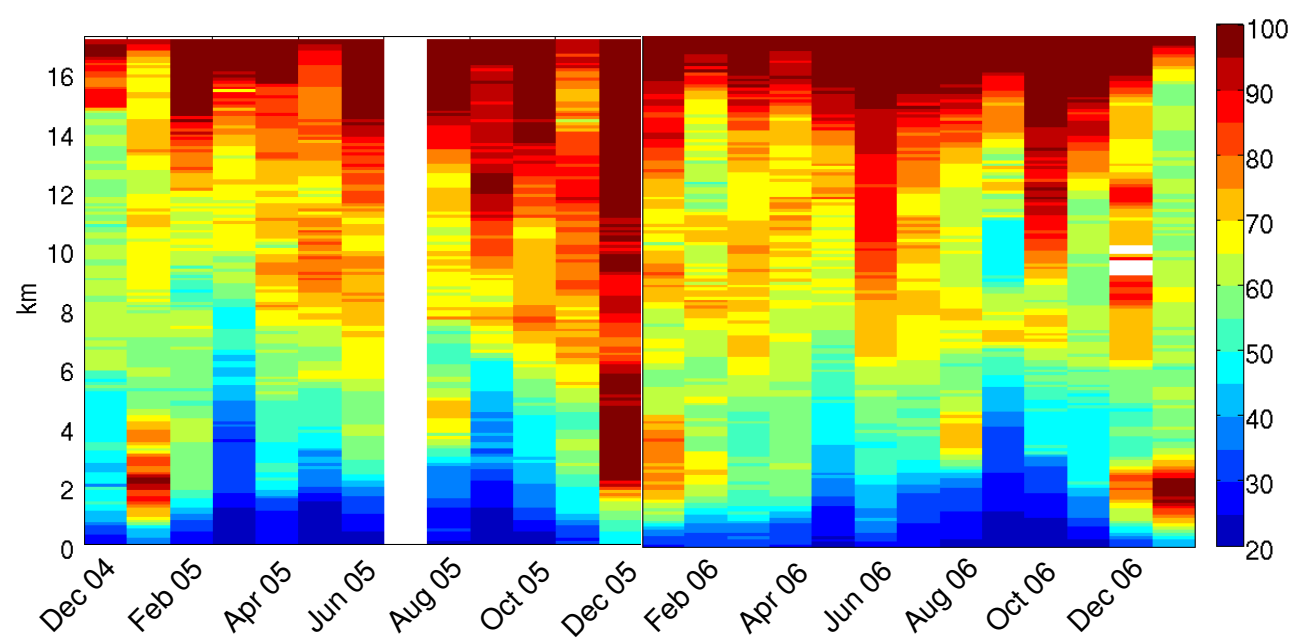

Fig. 10. 26 month timeseries of ozone (ppb) monthly means over Cotonou between 0 and $17 \mathrm{~km}$, averaged every $100 \mathrm{~m}$.

Figure 9 presents on overview of the interannual variability of the JJA profiles as seen in the AMMA program and in the MOZAIC measurements over Lagos. In August, the two mean profiles from soundings are similar while the MOZAIC profiles in 2000 and 2003 show the two distinct behaviours (with and without the southern intrusions, respectively). Cotonou data exhibit thicker ozone layers with higher concentrations compared to the aircraft data over Lagos. The years 2005 and 2006 seem to have had more favourable conditions for these southern intrusions. Within the MOZAIC data set, 28\% of the profiles in JJA 2003 presented such layers while the soundings time series (2005 and 2006) exhibited this phenomenon for $41 \%$ of the samples. The monthly mean for 2006 in July is closer to the one observed over Lagos in 2000, at least up to $5 \mathrm{~km}$ altitude. The mean vertical profiles in June do not present a well marked layer in general. Little signature of the southern intrusion is seen in 2005 and to a less extent in 2006 (only one profile presents such layers out of the 9 recorded).

Similar to the dry season, the AMMA SOP-2 took place in a rather "high ozone" environment with frequent enhanced layers originating from the southern hemisphere. The SOP-2 has also been characterized by the "extreme event" on $14 \mathrm{Au}-$ gust 2006 when up to $120 \mathrm{ppbv}$ were measured in the lower troposphere, a value similar to the highest measured during the dry season.

\section{Upper troposphere/lower stratosphere}

MOZAIC vertical profiles are limited to $12 \mathrm{~km}$, the aircraft cruise altitude, which is well below the tropical tropopause. The soundings have the capability of sampling ozone throughout the troposphere and the lower stratosphere (balloons have reached altitudes of $26 \mathrm{~km}$ ). Consequently they have provided the first data regarding the ozone distri- bution in the UTLS over West Africa. The aim of this section is to present the seasonal cycles of ozone and temperature in the UTLS.

Figure 10 shows the monthly mean time series of ozone concentrations averaged every $100 \mathrm{~m}$ from the ground to $17 \mathrm{~km}$ altitude between December 2004 and January 2007. The UT over Cotonou presents ozone concentrations higher than expected from the interpolation presented in Thompson et al. (2003b) and from the study by Sauvage et al. (2006) when they assumed the values of $70 \mathrm{ppb}$ recorded at $12 \mathrm{~km}$ to be valid up to the tropopause. This AMMA data set shows that ozone concentrations between 12 and $17 \mathrm{~km}$ are closer to 90-110 ppbv on average, and up to $150 \mathrm{ppbv}$ in August and September.

For further details of this UTLS region and for clarity of colour scale, Fig. 11a and $\mathrm{b}$ give the monthly mean ozone and temperature distributions between 12 and $22 \mathrm{~km}$ averaged every $100 \mathrm{~m}$. The white line on the figures gives an indication of the tropopause altitude. This has been defined as the lowest altitude where the temperature vertical gradient reaches the value of $-2 \mathrm{~K} / \mathrm{km}$. As expected, the tropopause altitude is around $17 \mathrm{~km}(16.9 \pm 0.4$ as standard deviation). However, from June to October the tropopause is a little bit lower and warmer than in the period from December to May. The difference is up to $10 \mathrm{~K}$, in agreement with Reed and Vicek (1969) and Reid and Gage (1981) and visible in both 2005 and 2006. The ozone seasonal cycle seems to be in phase with the well-known annual cycle of temperature. For better clarity we have averaged over the two years of sampling and we present the mean seasonal cycle of ozone concentrations and temperature at 12-14, 14-16, 16-17 and 17$18 \mathrm{~km}$ altitude in Fig. 12. The lowest layer shows no significant seasonal variation (70-80 ppb throughout the year) while a broad summer maximum of ozone is observed in the three upper layers. Nevertheless, the amplitude below $16 \mathrm{~km}$ 
(a)

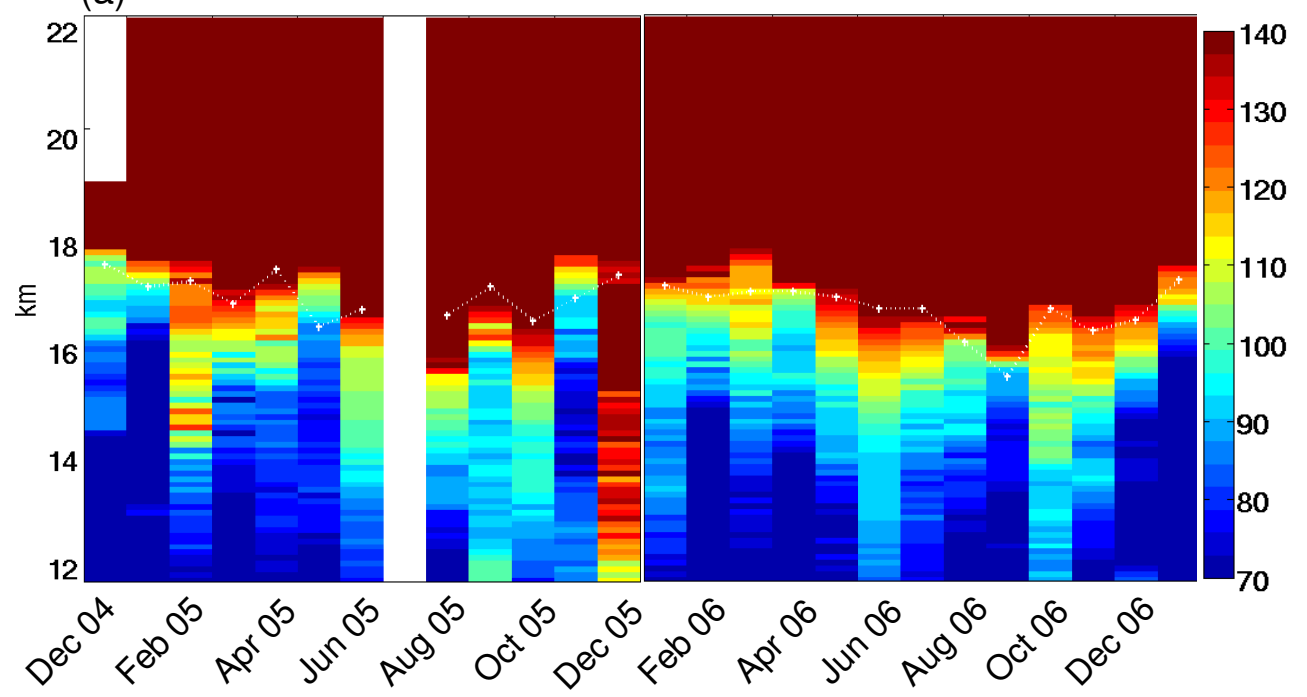

(b)

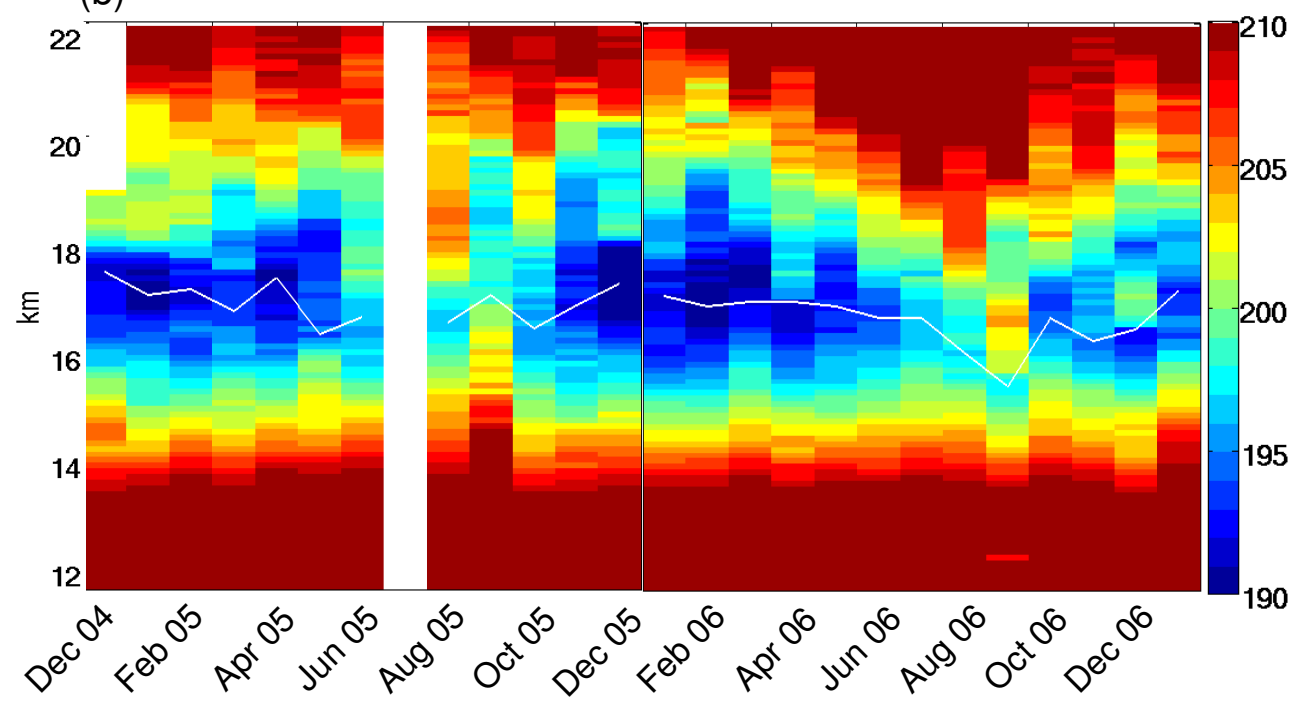

Fig. 11. 26 month timeseries of (a) ozone (ppb) and (b) temperature (K) monthly means over Cotonou between 12 and $22 \mathrm{~km}$, averaged every $100 \mathrm{~m}$.

is very weak (less than $20 \mathrm{ppb}$ or $20 \%$ ) while it increases to $50 \mathrm{ppb}$ at $16-17 \mathrm{~km}$ and up to around $150 \mathrm{ppb}$ or $100 \%$ in the layer just above the tropopause, at $17-18 \mathrm{~km}$. Concentrations between 17 and $18 \mathrm{~km}$ above Cotonou are in the range of 140-290 ppb, in agreement with that shown in Randel et al. (2007) based on a study of the SHADOZ profiles not including Cotonou. They linked this large annual cycle in ozone above the tropical tropopause to the variability of the Brewer-Dobson circulation. The amplitude of the temperature seasonal cycle is also higher above $17 \mathrm{~km}$ (up to $10 \mathrm{~K}$ ) compared to the tropospheric layers (less than $3 \mathrm{~K}$ ) and in phase with the ozone cycle, as expected. Ozone concentrations at $16-17 \mathrm{~km}$ are attributed to the upper troposphere and its seasonal cycle is very similar to the one just above the tropopause (17-18 km), but with a lower amplitude though. A similar pattern is observed for the temperature cycle. This may reflect a non-negligible influence of the stratosphere on the ozone distribution in the UT over Cotonou during the broad summer period (June to October).

This ozone data set is of particular interest for further investigation of the different origins of air masses recorded in the TTL (Tropical Tropopause Layer, between $150 \mathrm{hPa}$ or $14.5 \mathrm{~km}$ and $70 \mathrm{hPa}$ or $17 \mathrm{~km}$ as defined by Fueglistaler et al. (2009) and references therein) over this location throughout the year. Indeed, Barret et al. (2008) have shown the influence of the Indian Monsoon and the Tropical Easterly Jet on the composition of the TTL over Northern Africa. Moreover, Law et al. (2009) systematically analyzed the high altitude 
Table 2. Monthly mean tropospheric ozone columns (from the ground to the tropopause as calculated in Sect. 4) in Dobson Unit (DU) based on ozone soundings over Cotonou.

\begin{tabular}{|c|c|c|c|c|c|c|c|c|c|c|c|c|}
\hline & January & February & March & April & May & June & July & August & September & October & November & December \\
\hline 2004 & & & & & & & & & & & & 39.4 \\
\hline 2005 & 49.0 & 43.4 & 32.5 & 41.8 & 37.7 & 43.8 & - & 42.0 & 39.2 & 42.3 & 46.1 & 67.2 \\
\hline 2006 & 49.5 & 43.9 & 44.7 & 43.3 & 38.4 & 45.9 & 41.8 & 40.5 & 30.8 & 40.3 & 38.5 & 45.3 \\
\hline 2007 & 48.3 & & & & & & & & & & & \\
\hline
\end{tabular}
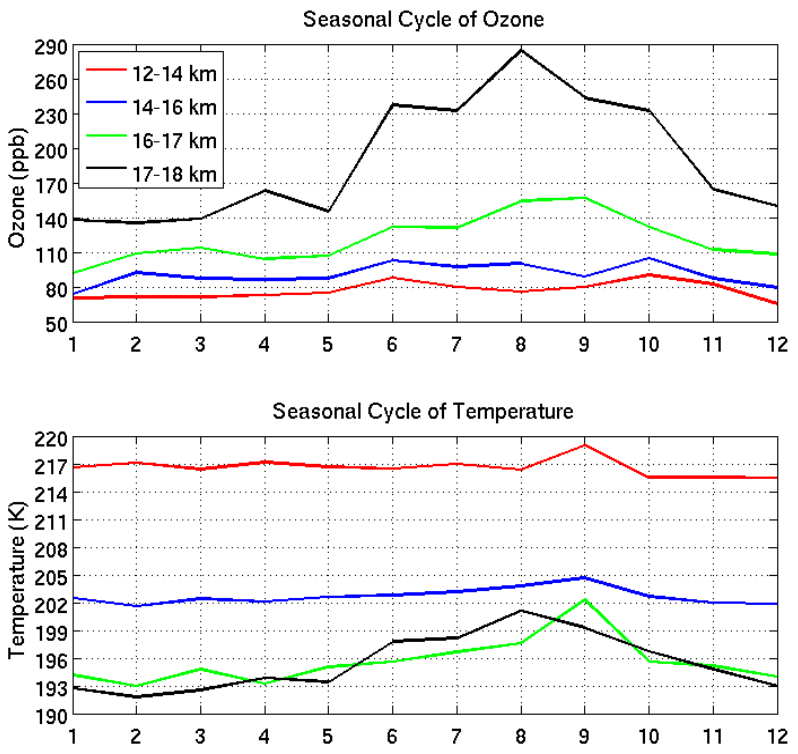

Fig. 12. Seasonal cycle of ozone (ppb) and temperature (K) averaged over the two years of the RS data set for four different layers, $12-14 \mathrm{~km}$ in red, $14-16 \mathrm{~km}$ in blue, $16-17 \mathrm{~km}$ in green and $17-$ $18 \mathrm{~km}$ in black.

aircraft data recorded during the SOPs in JJA 2006. They show that the region is mainly under the influence of African convection around $200 \mathrm{hPa}(12.5 \mathrm{~km})$, and of the Indian Monsoon around $150 \mathrm{hPa}(14.5 \mathrm{~km})$ while air masses sampled around $100 \mathrm{hPa}(17 \mathrm{~km})$ are related to stratospheric origins.

\section{Tropospheric columns of ozone}

This present data set is actually the first one that allows a thorough quantification of tropospheric columns of ozone (TCO) over West Africa. The objectives of this section are to present the seasonal variations of these TCO and to compare them with satellite retrievals. Comparisons are based on monthly means to evaluate the seasonal and interannual variations of the columns. The goal is not a thorough comparison to the satellite data on a daily basis. Given that the satellite data are the only available records representative of monthly mean columns over this region, we aim to check whether our data set matches them despite its low sampling frequency.

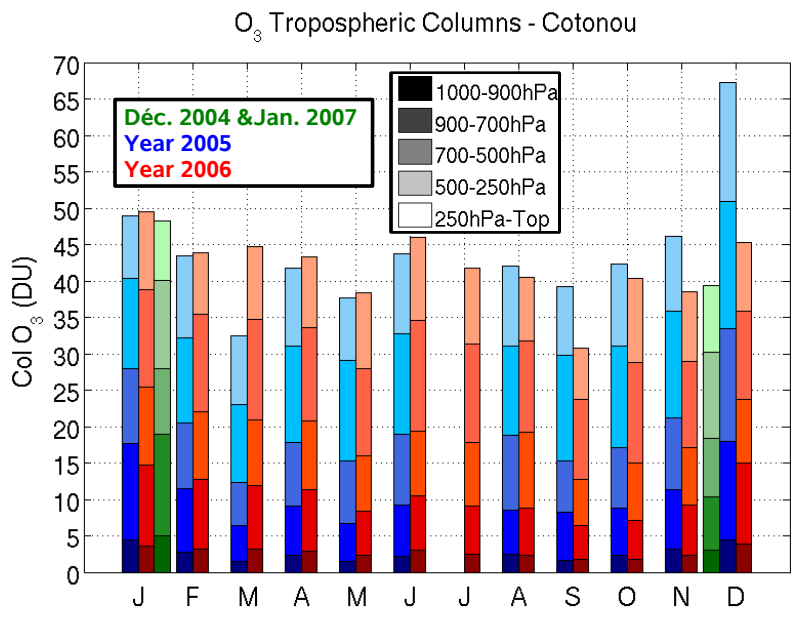

Fig. 13. Monthly mean tropospheric columns of ozone in Dobson Unit (DU) over Cotonou between December 2004 and January 2007. Columns are divided into 5 layers from $1000 \mathrm{hPa}$ to the tropopause (called Top and calculated as defined in Sect. 4). Each year corresponds to one color: blue for 2005, red for 2006 and green for December 2004 and January 2007.

Meanwhile, we specifically discuss the sensitivity of remote instruments in the lower troposphere.

\subsection{Seasonal variations}

Figure 13 and Table 2 present the annual variations of monthly mean TCO derived from the soundings and calculated in Dobson Unit (DU, $1 \mathrm{DU}=2.69 \times 10^{16}$ molecules $\mathrm{cm}^{-2}$ ). The TCO range from 32.5 to $67.2 \mathrm{DU}$, with high annual and interannual variabilities (up to $20 \mathrm{DU}$ ). March, September and December show the strongest interannual variability. To better assess which atmospheric layer contributes to these variabilities, the TCO were divided into 5 layers, related to air masses origin. The first layer from 1000 to $900 \mathrm{hPa}$ is under monsoon flux influence, the air masses coming from S-SW. The second layer $(900-700 \mathrm{hPa})$ roughly corresponds to the Harmattan layer during boreal winter (DJF) and to trade winds during boreal summer (JJA). The third one from 700 to $500 \mathrm{hPa}$ generally relates to the African Easterly Jet altitude, with large scale transport influence. The fourth and 


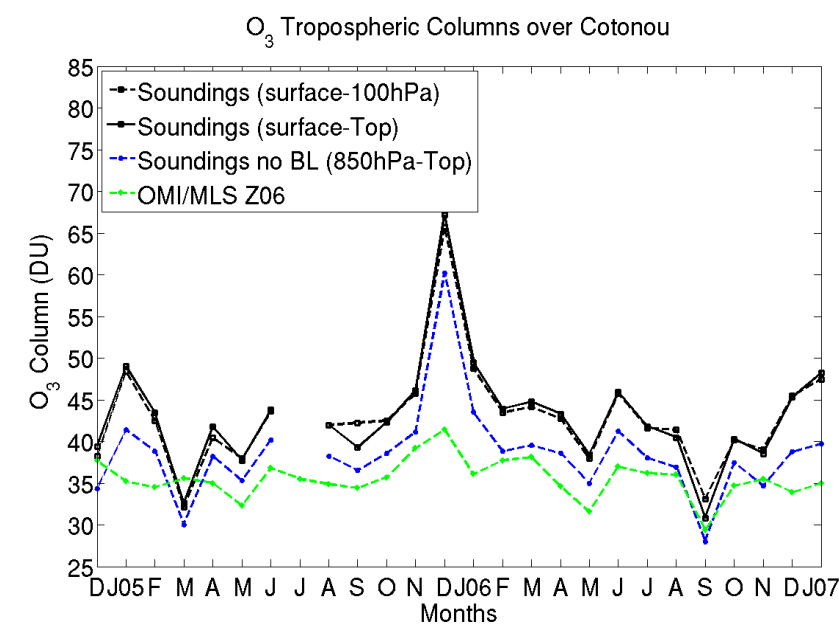

Fig. 14. Time evolution between December 2004 and January 2007 of the monthly mean tropospheric columns of ozone in DU from OMI/MLS Ziemke et al. (2006) (green dashed line) and derived from the ozone soundings from the surface to $100 \mathrm{hPa}$ (dark dashed line),the surface to the tropopause (called Top and calculated as defined in Sect. 4) (dark solid line), and $850 \mathrm{hPa}$ to the tropopause (blue dashed line.

fifth ones represent for mid-upper and upper tropospheric layers which can be both effected by large scale transport and deep convection. The fifth one is also influenced by the lower stratosphere as seen in Sect. 4. The tropospheric ozone columns show little difference between 2005 and 2006 (2-3 DU) except for the beginning of the dry season (November and December) and the months of March and September (Fig. 13).

The seasonal variations appear to be largely driven by the first three layers partly due to surface emission changes between dry and wet seasons. A maximum of partial TCO is clearly seen during the dry season (DJF) when emissions from biomass burning maximize with around 15 DU from the surface up to $700 \mathrm{hPa}$ whilst rarely exceeding $10 \mathrm{DU}$ the rest of the year. The mean ozone column amount averaged over the DJF season show 48 DU over Cotonou which is higher than that found over Lagos (41 DU) by Sauvage et al. (2006) using MOZAIC data. The difference in total ozone amount can be partly attributed to the climatological values of $70 \mathrm{ppbv}$ between 186 and $100 \mathrm{hPa}$ used by Sauvage et al. (2006) to augment MOZAIC vertical profiles. Figures 11a and 12 have shown that ozone values over Cotonou can reach up to $130 \mathrm{ppbv}$ near the tropopause, higher than the assumed value used in their study. Nevertheless interannual and geographical variabilities might be part of the difference too. The ozone column below $700 \mathrm{hPa}$ contributes to 14.9 DU of the TOC in DJF which is in fairly good agreement with the Sauvage et al. (2006) results over Lagos (17.3 DU).

In the following, some observed interannual variabilities are highlighted. However our goal is more to give a first as- sessment of this tropospheric ozone variability and its probable causes rather than a detailed explanation of them that would require further studies. A $12 \mathrm{DU}$ difference, essentially confined to the lower layers (below $500 \mathrm{hPa}$ ), is calculated between March 2005 and March 2006 showing a lower (higher) amount of ozone in 2005 (2006). Such a difference is less pronounced in February and April. However OMI/MLS does not capture this difference (Fig. 14 and next subsection), suggesting that unfortunately sparse sampling (3 soundings each month) might be responsible of this difference. A 8.4 DU difference is calculated between September 2005 and September 2006 showing a lower amount of UT ozone in 2006 in agreement with the mean ozone profiles in Fig. 3. Only three ozone soundings were performed for each September month; however this difference is supported by OMI/MLS TCO retrievals (Fig. 14 and next subsection). NCEP Reanalysis show lower Outgoing Long wave Radiation (OLR) above Western and Equatorial Africa in September 2006 compared to September 2005 (not shown). Thus more convective events in 2006 decreasing UT ozone by uplifting poor ozone air masses from the boundary layer are likely to be responsible for part of the variability between the sampled profiles. More specific studies should be made to investigate these hypotheses. Lower ozone columns are found during the dry season 2006 compared to 2005 with $-7.6 \mathrm{DU}$ (20\%) and -21.9 DU (48\%) in November and December, respectively. The monthly mean profiles for December (Figs. 3 and 6) show that the differences are essentially in the lower troposphere under the AEJ influence (above the Harmattan layer and below $5 \mathrm{~km}$ or $500 \mathrm{hPa}$ ) and in the upper troposphere (above $10 \mathrm{~km}$ ). Those two parts contribute equally to the interannual difference. $61 \%$ and $48 \%$ of this difference is confined in the lower troposphere below $500 \mathrm{hPa}$ in November and December respectively. The variability in the lower part of the troposphere is probably due to enhanced biomass burning emissions in 2005 in Africa (as discussed previously in Sect. 3.1.2). Logan et al. (2008) also found lower ozone in the middle troposphere over Equatorial Africa in December 2006 compared to 2005 using data from the Tropospheric Emission Spectrometer (TES) and suggested that these changes could be related to the late 2005 drought in eastern Africa leading to enhanced biomass burning as well as lower $\mathrm{NO}_{\mathrm{x}}$ production from lightning in $2006 \mathrm{com}-$ pared to 2005 leading to lower ozone production in the UT in 2006. The 2005-2006 difference in the upper part of the troposphere might be due to enhanced convection in December 2005 leading to more $\mathrm{NO}_{\mathrm{x}}$ in the UT and more biomass burning pollutants up-lifted, which favour enhanced ozone production.

A secondary maximum is seen in JJA related to biomass burning plume intrusions from the Southern Hemisphere as discussed in Sect. 3.2. Here we attempt to assess the contribution of the Southern Hemisphere influence on the tropospheric ozone total amount by selecting and comparing two groups of ozone profiles (with and without ozone 
Table 3. Mean tropospheric ozone columns in DU over Cotonou during July and August for profiles with and without an ozone enhancement around $700-500 \mathrm{hPa}$. Standard deviation for each group appears in brackets.

\begin{tabular}{lrrrrrr}
\hline & $1000-900 \mathrm{hPa}$ & $900-700 \mathrm{hPa}$ & $700-500 \mathrm{hPa}$ & $500-250 \mathrm{hPa}$ & $250 \mathrm{hPa}-\mathrm{Top}$ & $1000 \mathrm{hPa}-\mathrm{Top}$ \\
\hline With O 3 layer & $2.45( \pm 0.42)$ & $6.95( \pm 1.3)$ & $11.20( \pm 2.10)$ & $11.41( \pm 3.00)$ & $9.50( \pm 2.20)$ & $41.40( \pm 3.97)$ \\
$\mathrm{W}_{\mathrm{o}} \mathrm{O}_{3}$ layer & $2.40( \pm 0.56)$ & $5.42( \pm 0.76)$ & $7.74( \pm 0.59)$ & $13.07( \pm 1.66)$ & $9.52( \pm 1.49)$ & $37.94( \pm 3.30)$ \\
Diff (W-W/o $)$ & 0.05 & 1.53 & 3.46 & -1.66 & 0.02 & 3.46 \\
\hline
\end{tabular}

enhancement). For this comparison we use only July and August profiles to avoid the variations of upper tropospheric ozone levels which are clearly higher in June compared to July and August. During July and August 2005 and 2006, 18 ozone soundings were performed and 10 of them present an ozone layer located between $750 \mathrm{hPa}$ and $500 \mathrm{hPa}$. When processing these two groups of profiles separately, we found a 3.5 DU difference in the total tropospheric ozone amount (41.4 DU and 37.9 DU for profiles with and without the ozone layer, respectively, see Table 3). Ozone enhancements from southern biomass burning pollution are located between $750 \mathrm{hPa}$ and $500 \mathrm{hPa}$, consequently the biomass burning influence is seen mostly in the third level $(700-500 \mathrm{hPa})$ and little in the second level $(900-700 \mathrm{hPa})$. Therefore, a difference of $5 \mathrm{DU}$ between 900 and $500 \mathrm{hPa}$ is computed. However this positive difference is balanced by a $1.7 \mathrm{DU}$ negative difference between 500 and $100 \mathrm{hPa}$. These results are consistent with those found by Mari et al. (2008) and support the hypotheses of a mid-troposphere enrichment of $\mathrm{CO}$ and ozone from biomass burning during the active phase of the southern AEJ (AEJ-S) whilst during its break phase, pollutants are first confined to the continent where they can reach a convective region further north and then be up-lifted to the upper troposphere. The up-lifting of biomass burning pollutants from the southern hemisphere contribute to the 1.66 DU. However, the electrical activity associated with the convective systems produces nitrogen oxides which may also enhance ozone levels in the UT (e.g. Smyth et al., 1996; Pickering et al., 1996; Moxim and Levy, 2000; Martin et al., 2000; DeCaria et al., 2005; Sauvage et al., 2007d; Saunois et al., 2008a). Overall the biomass burning pollution from the Southern Hemisphere influences West Africa, at least the region of the Guinean coast close to Cotonou, either in the mid- or in the upper-troposphere depending on meteorological conditions and leads to up to 5 DU (12\%) ozone enhancement in July and August.

\subsection{Comparison between ozone soundings and OMI/MLS tropospheric residuals}

Since the launch of Aura on 15 July 2004, tropospheric ozone columns or residuals can be derived by subtracting the stratospheric column estimated by Aura MLS (Microwave Limb Sounder) from the total ozone column measured by Aura OMI (Ozone Monitoring Instrument). OMI/MLS tro- pospheric ozone residuals (TOR) have been compared with ozonesondes by Ziemke et al. (2006) (denoted as Z06 in the following) in the tropics and outside the tropics using a pressure-averaged ozone volume mixing ratio (VMR). The tropopause pressure used by Z06 was determined from NCEP reanalysis using the $2 \mathrm{~K} / \mathrm{km}$ thermal vertical gradient criterion and corresponds to an average of $100 \mathrm{hPa}(\sim 17 \mathrm{~km})$ in the tropics with a range from 95 to $110 \mathrm{hPa}$ over the two year period. Z06 did not find a substantial offset relative to ozonesondes using a pressure-averaged ozone mixing ratio (VMR). However their highest differences corresponded to tropical SHADOZ stations, Natal and Ascension with 5.9 and $3.1 \mathrm{ppbv}$. They found an average offset of 2 DU between OMI/MLS and several WOUDC/SHADOZ stations and pointed out that considering VMR reduces the scatter. Schoeberl et al. (2007) (denoted as S07 in the following) estimate the 200-hPa-to-surface ozone column using a trajectory model to increase the horizontal resolution of the stratospheric columns derived from MLS. Their product, TTOR 200TSC, shows an improvement over Z06, especially in the mid-latitudes. They bilinearly interpolate their TTOR 200TSC product to compare with ozonesonde points. They found a $2.4 \mathrm{DU}$ offset in the tropics, with TTOR 200TSC being lower and a $5 \mathrm{DU}$ standard deviation probably representing the total uncertainty of the measurements.

In Fig. 14, we compare the monthly means of OMI/MLS TOR derived by Z06 and publicly available from the NASA Goddard web page (http://hyperion.gsfc.nasa.gov/ Data_services/cloud_slice) with the monthly means of ozonesonde columns (calculated from the ground to the altitude of the tropopause as defined in Sect. 4). The comparison shows a good agreement between ozonesondes and OMI/MLS tropospheric columns. In particular they both agree for smaller values in May 2005 and 2006 and September 2006. Although similar, amplitudes of the seasonal cycle and interannual variability seem weaker in OMI/MLS data set. During the 26 month period, the highest tropospheric ozone amount over Cotonou was measured in December 2005 by the ozone soundings. This extreme value is also reported by OMI/MLS, but to a lesser extent though. The OMI/MLS tropospheric column reaches up to 41.4 DU in December 2005 whilst its mean value is 35.5 DU through the 26 months (i.e. 17\% higher). Generally, OMI/MLS tropospheric residuals from Z06 exhibit a significant negative offset relative to ozonesondes: 11.8 DU and 6.7 DU in DJF 
Table 4. Mean tropospheric ozone columns in DU over Cotonou during DJF and JJA for OMI/MLS and ozonesonde columns and their absolute and relative differences. RS1 correspond to the columns from the surface up to the tropopause level and RS2 correspond to the columns from $850 \mathrm{hPa}$ up to the tropopause.

\begin{tabular}{|c|c|c|}
\hline & Mean DJF & Mean JJA \\
\hline OMI/MLS (DU) & 36.4 & 36.1 \\
\hline RS1 (surf-Top) (DU) & 48.2 & 42.8 \\
\hline RS2 (850 hPa-Top) (DU) & 41.9 & 38.9 \\
\hline RS1-sat (DU) RS1-sat (\%) & $24.5 \%$ & $15.7 \%$ \\
\hline RS2-sat (DU) RS2-sat (\%) & $13.1 \%$ & $7.2 \%$ \\
\hline
\end{tabular}

and JJA, respectively (Table 4). Those results are greater than those found by Z06 or S07. The different sampling frequency of ozonesondes ( 3 to 9 days a month) and of satellite data (almost everyday) used to compute monthly means as well as the missing ozone variation within the pixel size of OMI/MLS data $\left(1^{\circ} \times 1.25^{\circ}\right)$ are two basic sources of discrepancy for such a comparison. This could be the main reason for large differences observed in December 2005 when 2 out of our 3 profiles were characteristics of an extreme small scale event. Also MLS stratospheric columns are biased such that they are slightly high by a few DU and assuming no bias for the OMI column, the TTOR would also be low by a few DU (S07). Z06 explicitly added ozone based on a recent evaluation of OMI and MLS offset differences (S07). However the MLS high bias does not explain our 7-12 DU differences.

Compared to Cotonou, most of the SHADOZ stations are subject to low amounts of pollution and pretty clean near the surface. Considering that OMI is not very sensitive near the surface due to strong Rayleigh scattering (S07), we have computed ozonesonde TCO minus the lowest layers below $850 \mathrm{hPa}$. These reduced columns compare better with the OMI/MLS tropospheric residuals (Fig. 14) and diminish the offsets to 5.5 DU and 2.8 DU for DJF and JJA, respectively (Table 3). These results are consistent with the low sensitivity of OMI in the boundary layer. Also using a model comparison Z06 noticed that a band of +10 DU difference centered over Northern Africa is persistent and coincides with mineral dust plumes from desert. This discrepancy was not explained but they suggested that desert dust affects either OMI measurements or the model. This assumption is in agreement with our higher difference in DJF compared to JJA; in DJF the Harmattan flux transporting mineral dust from the Sahara as well as biomass burning pollution reaches the Guinean coast, and so Cotonou. A sensitivity test to the tropopause pressure of the column show that the ozone amount is not significantly affected by the tropopause pressure chosen (Fig. 14).

\section{Conclusions}

In this paper, we have presented the first ozone data set obtained through balloon-sondes launches in West Africa. During the AMMA campaign, a total of 98 vertical profiles over Cotonou, Benin, were measured over a 26 month period. These regular measurements document the seasonal and interannual variability of ozone in both the troposphere and the lower stratosphere over West Africa for the first time. This data set complements the MOZAIC observations made from Lagos between 0 and $12 \mathrm{~km}$. Moreover it provides a first assessment of the ozone distribution in the UTLS and gives the first tropospheric columns of ozone based on in-situ data over West Africa.

The comparison with aircraft data has shown that the ozone concentrations from the soundings are in reasonable agreement with the ones recorded by UV analyzers. As expected, Cotonou ozone soundings show the same seasonal characteristics as those derived from the MOZAIC measurements over Lagos in the lower and mid-troposphere. Both data sets highlight the unique way in which West Africa is impacted by two biomass burning seasons from two different hemispheres. This leads to ozone enhanced layers in the lower troposphere in DJF (due to burning in the Sahelian band) and in JJA (due to burning in southern Africa) as previously described by Sauvage et al. $(2005,2007$ a) and Mari et al. (2008). Even though a $20 \%$ average difference has been calculated between the MOZAIC data and ozone soundings measurements between 2 and $8 \mathrm{~km}$, no systematic difference has been found between the two data sets. On the contrary, high variabilities appear in each data set (examples of July and August for MOZAIC, March, September and December for the soundings). Thus, the rather high interannual variability of the ozone profiles throughout the troposphere is found to be a major characteristic of this region and has been highlighted in most of the sections. The example of the dry season 2005-2006 shows that the influences of biomass burning emission and dynamics changes on the ozone amount are large. This study has also shown that the enhancement of ozone originating from the biomass burning products in the Southern Hemisphere was more frequent during the wet seasons of 2005 and 2006 than previously established based on the MOZAIC data set with $41 \%$ of the profiles showing ozone enhancement compared to $28 \%$. This major feature should be considered when analyzing this period. The high interannual variability of ozone in this region seems to be related to the multiplicity of the trace gas sources with their own variabilities (biomass burning, lightning, megacity of Lagos) and also to the particular atmospheric circulation. This latter factor combines the characteristics of a transition zone between the monsoon and Harmattan flows and a region under monsoon and convective influences; the three of them have significant temporal variations. Indeed, such variabilities might be typical of Equatorial Africa. Since December 2005, a MOZAIC aircraft has been operated by 
Air Namibia and sampled the upper troposphere between Windhoek, Namibia and Europe. The mean ozone values in the UT around $6^{\circ} \mathrm{N}-7^{\circ} \mathrm{N}$ along the flight tracks also show high interannual variability with differences of up to 20-30\% from one year to the next especially in February, May, June, October and December (J-P. Cammas, personal communication). As the flights go east of Cotonou and Lagos $(\sim 10$ $15^{\circ} \mathrm{E}$ ), a quantitative comparison would not have been relevant here. However, the Air Namibia data set confirms the high interannual variabilities of ozone concentrations in the African upper troposphere.

The West African UTLS shows the same patterns regarding the ozone and temperature annual cycle, as those found over other tropical stations. However the ozone concentrations registered in the UTLS above Cotonou are higher than expected from previous tropical studies. Ozone concentrations range around 90-110 ppbv on average between 12 and $17 \mathrm{~km}$, and reach up to $150 \mathrm{ppb}$ in August and September. A first quantification of tropospheric ozone columns based on in-situ data has been derived over Cotonou. They maximize in DJF with $45 \mathrm{DU}$ on average. Such a value is higher than the one calculated by Sauvage et al. (2006) from the MOZAIC profiles over Lagos (41 DU). This difference is mainly attributed to their underestimate of the ozone distribution in the upper troposphere. These tropospheric columns derived from the ozonesoundings have been compared to satellite data and a qualitative good agreement has been found with the OMI/MLS tropospheric column. Quantitatively, the difference is around 7-12 DU and can be reduced to 3-6 DU if we omit the lowest layers of the troposphere (below $850 \mathrm{hPa}$ ) in the calculation from the soundings, suggesting that much of the negative bias may be attributed to the lack of sensitivity of OMI to the boundary layer.

The AMMA program has allowed the acquisition of the data set presented here that has already been used for various studies such as satellite validations (Schoeberl et al., 2007; Jiang et al., 2007), data analysis (Reeves et al., 2009) and models studies (Mari et al., 2008; Williams et al., 2009b,a). We believe its use will last long after the AMMA programme. Quantifying the tropospheric ozone budget over West Africa will require further analysis. For example it is still a challenge for Chemical Transport Models to be able to reproduce these seasonal characteristics (Saunois et al., 2008b; Williams et al., 2009b,a).

Acknowledgements. Based on a French initiative, AMMA was built by an international scientific group and is currently funded by a large number of agencies, especially from France, the United Kingdom, the United States, and Africa. It has been the beneficiary of a major financial contribution from the European Community's Sixth Framework Research Programme. Detailed information on scientific coordination and funding is available on the AMMA International Web site at www.amma-international.org. Besides, authors warmly thank all the people from IRD based in Cotonou for their help before, during and after this sounding operation, as well as Mr Francis Didé, from SMN/ASECNA. Finally, collaborations with Mrs Aristide Akpo, Etienne Houngninou and Basile Kounouhewa from the University of Abomey-Calavi have been really appreciated.

Edited by: J. Williams

\section{References}

Aghedo, A. M., Schultz, M. G., and Rast, S.: The influence of African air pollution on regional and global tropospheric ozone, Atmos. Chem. Phys., 7, 1193-1212, 2007, http://www.atmos-chem-phys.net/7/1193/2007/.

Ancellet, G., Leclair de Bellevue, J., Mari, C., Nedelec, P., Kukui, A., Borbon, A., and Perros, P.: Effects of regional-scale and convective transports on tropospheric ozone chemistry revealed by aircraft observations during the wet season of the AMMA campaign, Atmos. Chem. Phys., 9, 383-411, 2009, http://www.atmos-chem-phys.net/9/383/2009/.

Andreae, M. and Merlet, P.: Emission of trace gases and aerosols from biomass burning, Global Biogeochem Cy., 15, 955-966, 2001.

Andrès-Hernández, M. D., Kartal, D., Reichert, L., Burrows, J. P., Meyer Arnek, J., Lichtenstern, M., Stock, P., and Schlager, H.: Peroxy radical observations over West Africa during the AMMA 2006 campaign: Photochemical activity in episodes of formation of convective systems on the basis of radical measurements, Atmos. Chem. Phys., 9, 3681-3695, 2009, http://www.atmos-chem-phys.net/9/3681/2009/.

Barnes, R. A., Bandy, A. R., and Torres, A. L.: Electrochemical concentration cell ozone sonde accuracy and precision, J. Geophys. Res., 90, 7881-7887, 1985.

Barret, B., Ricaud, P., Mari, C., Attié, J.-L., Bousserez, N., Josse, B., Le Flochmoën, E., Livesey, N. J., Massart, S., Peuch, V.-H., Piacentini, A., Sauvage, B., Thouret, V., and Cammas, J.-P.: Transport pathways of $\mathrm{CO}$ in the African upper troposphere during the monsoon season: a study based upon the assimilation of spaceborne observations, Atmos. Chem. Phys., 8, 3231-3246, 2008,

http://www.atmos-chem-phys.net/8/3231/2008/.

Beekmann, M., Ancellet, G., Mégie, G., Smit, H. G. J., and Kley, D.: Intercomparison campaign of vertical ozone profiles including electrochemical sondes of ECC and Brewer-Mast Type-A ground-based UV-differential absorption lidar, J. Atmos. Chem., 19, 259-288, 1994.

Cros, B., Fontan, J., Minga, A., Helas, G., Nganga, D., Delmas, R., Chapuis, A., Benech, B., Druilhet, A., and Andrea, M.: Vertical profiles of ozone between 0 and $400 \mathrm{~m}$ in and above an African Equatorial forest, J. Geophys. Res., 97, 12 877-12 877, 1992.

Cros, B., Delon, C., Affre, C., Marion, T., Druilhet, A., Perros, P., and Lopez, A.: Sources and sinks of ozone in savanna forest areas during EXPRESSO: Airborne turbulent flux measurements, J. Geophys. Res., 105, 29347-29358, 2000.

DeBacker, H., Demuer, D., and De Sadelaer, D.: Comparison of ozone profiles obtained with Brewer-Mast and Z-ECC sensors during simultaneous ascents, J. Geophys. Res., 103, 19641$19648,1998$.

DeCaria, A., Pickering, K., Stenchikov, G., and Ott, L.: Lightninggenerated $\mathrm{NO}_{\mathrm{x}}$ and its impact on tropospheric ozone production: 
A three dimensional modeling study of a StratosphereTroposphere Experiment: Radiation, Aerosols and Ozone (STERAO-A) thunderstom, J. Geophys. Res., 110, D14303, doi:10.1029/2004JD005556, 2005.

Delmas, R. A., Druilhet, A., Cros, B., et al.: Experiment for Regional Sources and Sinks of Oxidants (EXPRESSO): An overview, J. Geophys. Res., 104, 30 609-30 624, 1999.

Deshler, T., Mercer, J., Smit, H. G. J., et al.: Atmospheric comparison of electrochemical cell ozonesondes from different manufacturers, and with different cathode solution strengths: The Balloon Experiment on Standards for Ozonesondes, J. Geophys. Res., 113, D04307, doi:10.1029/2007JD008975, 2008.

Edwards, D. P., Lamarque, J.-F., Attie, J.-L., Emmons, L. K., Richter, A., Cammas, J.-P., Lyjak, L. V., Francis, G. L., Gille, J. C., and Drummond, J.: Tropospheric ozone over the tropical Atlantic: A satellite perspective, J. Geophys. Res., 108, 4237, doi:10.1029/2002JD002927, 2003.

Fueglistaler, S., Dessler, A., Dunkerton, T. J., Folkins, I., Fu, Q., and Mote, P. W.: Tropical tropopause layer, Rev. Geophys., 47, RG1004, doi:10.1029/2008RG000267, 2009.

Guenther, A., Karl, T., Harley, P., Wiedinmyer, C., Palmer, P. I., and Geron, C.: Estimates of global terrestrial isoprene emissions using MEGAN (Model of Emissions of Gases and Aerosols from Nature), Atmos. Chem. Phys., 6, 3181-3210, 2006, http://www.atmos-chem-phys.net/6/3181/2006/.

Guenther, A., Hewitt, C. N., Erickson, D., Fall, R., Geron, C., Graedel, T., Harley, P., Klinger, L., Lerdau, M., McKay, W. A., Pierce, T., Scholes, B., Steinbrecher, R., Tallamraju, R., Taylor, J., and Zimmerman, P.: A global model of natural volatile organic compound emissions, J. Geophys. Res., 100, 8873-8892, 1995.

Haywood, J., Pelon, J., Formenti, P., et al.: Overview of the dust and biomass-burning experiment and African Monsoon multidisciplinary analysis special observing period-0, J. Geophys. Res., 113, D00C17, doi:10.1029/2008JD10077, 2008.

Höller, H., Betz, H.-D., Schmidt, K., Calheiros, R. V., May, P., Houngninou, E., and Scialom, G.: Lightning characteristics observed by a VLF/LF lightning detection network (LINET) in Brazil, Australia, Africa and Germany, Atmos. Chem. Phys. Discuss., 9, 6061-6146, 2009,

http://www.atmos-chem-phys-discuss.net/9/6061/2009/.

Jacob, D. J., Heikes, E. G., Fan, S.-M., et al.: Origin of ozone and NOx in the tropical troposphere: A photochemical analysis of aircraft observations over the South Atlantic basin, J. Geophys. Res., 101, 23 889-23 907, 1996.

Jaeglé, L., Martin, R., Chance, K., Steinberger, L., Kurosu, T., Jacob, D., Modi, A., Yobou, V., Sigha-Nkamdjou, L., and Galy-Lacaux, C.: Satellite mapping of rain-induced nitric oxide emissions from soils, J. Geophys. Res., 109, D21310, doi:10.1029/2004JD004787, 2004.

Jaeglé, L., Steinberger, L., Martin, R., and Chance, K.: Global partitionning of $\mathrm{NO}_{\mathrm{x}}$ sources using satellite observations: relative roles of fossil fuel combustion, biomass burning and soils emissions, Faraday Discuss., 130, 1-17, 2005.

Janicot, S., Thorncroft, C. D., Ali, A., Asencio, N., Berry, G., Bock, O., Bourles, B., Caniaux, G., Chauvin, F., Deme, A., Kergoat, L., Lafore, J.-P., Lavaysse, C., Lebel, T., Marticorena, B., Mounier, F., Nedelec, P., Redelsperger, J.-L., Ravegnani, F., Reeves, C. E., Roca, R., de Rosnay, P., Schlager, H., Sultan, B., Tomasini,
M., Ulanovsky, A., and ACMAD forecasters team: Large-scale overview of the summer monsoon over West Africa during the AMMA field experiment in 2006, Ann. Geophys., 26, 25692595, 2008, http://www.ann-geophys.net/26/2569/2008/.

Jenkins, G. S. and Ryu, J. H.: Space-borne observations link the tropical atlantic ozone maximum and paradox to lightning, Atmos. Chem. Phys., 4, 361-375, 2004, http://www.atmos-chem-phys.net/4/361/2004/.

Jiang, Y. B., Froidevaux, L., Lambert, A., et al.: Validation of Aura Microwave Limb Sounder Ozone by ozonesonde and lidar measurements, J. Geophys. Res., 112, D24S34, doi:10.1029/2007JD008776, 2007.

Jonquière, I., Marenco, A., Maalej, A., and Rohrer, F.: Study of ozone formation and transatlantic transport from biomass burning emissions over West Africa during the airborne Tropospheric Ozone Campaigns TROPOZ I and TROPOZ II, J. Geophys. Res., 103, 19 059-19 073, 1998.

Komhyr, W. D.: Nonreactive gas sampling pump, Rev. Sci. Instrum., 38, 981-983, 1967.

Komhyr, W. D.: Operations handbook ozone measurements to $40 \mathrm{~km}$ altitude with model 4A-ECC-ozone sondes, Tech. rep., NOAA Tech. Memo. ERL-ARL-149, 1986.

Komhyr, W. D., Barnes, R. A., Brothers, G. B., Lathrop, J. A., and Opperman, D. P.: Electrochemical concentration cell ozonesonde performance during STOIC, J. Geophys. Res., 100, 9231-9244, 1995.

Law, K., Cairo, F., Fierli, F., et al.: Air mass origins influencing TTL chemical composition over West Africa during 2006 summer monsoon, Atmos. Chem. Phys. Discuss., in preparation, 2009.

Logan, J., Megretskaia, I., Nassar, R., et al.: Effects of the 2006 El Nino on tropospheric composition as revealed by data from the Tropospheric Emission Spectrometer (TES), Geophys. Res. Lett., 35, L03816, doi:10.1029/2007GL031698, 2008.

Mallet, M., Pont, V., Liousse, C., Gomes, L., Pelon, J., Osborne, S., Haywood, J., Roger, J. C., Dubuisson, P., Mariscal, A., Thouret, V., and Goloub, P.: Aerosol direct radiative forcing over Djougou (northern Benin) during the African Monsoon Multidisciplinary Analysis dry season experiment (Special Observation Period-0), J. Geophys. Res., 113, D00C01, doi:10.1029/2007JD009419, 2008.

Marenco, A., Thouret, V., Nédélec, P., Smit, H., Helten, M., Kley, D., Karcher, F., Simon, P., Law, K., Pyle, J., Poschmann, G., Von Wrede, R., Hume, C., and Cook, T.: Measurement of ozone and water vapor by airbus in-service aircraft: The MOZAIC airborne program, An Overview, J. Geophys. Res., 103, 25 631-25 642, 1998.

Mari, C. H., Cailley, G., Corre, L., Saunois, M., Attié, J. L., Thouret, V., and Stohl, A.: Tracing biomass burning plumes from the Southern Hemisphere during the AMMA 2006 wet season experiment, Atmos. Chem. Phys., 8, 3951-3961, 2008, http://www.atmos-chem-phys.net/8/3951/2008/.

Martin, R., Jacob, D. L. J., Ziemke, J., and Washington, R.: Detection of a lightning influence on tropical tropospheric ozone, Geophys. Res. Lett., 27, 1639-1642, 2000.

Martin, R. V., Jacob, D. J., Logan, J. A., Bey, I., Yantosca, R. M., Staudt, A. C., Li, Q. B., Fiore, A. M., Duncan, B. N., Liu, H., Ginoux, P., and Thouret, V.: Interpretation of TOMS 
observations of tropical tropospheric ozone with a global model and in situ observations, J. Geophys. Res., 107(D18), 4351, doi:10.1029/2001JD000462, 2002.

Minga, A., Thouret, V., Saunois, M., Delon, C., Mari, C., Serca, D., Sauvage, B., Mariscal, A., Leriche, M., and Cros, B.: High ozone concentrations over Cotonou in december 2005 as observed in the frame of the AMMA program, Atmos. Chem. Phys. Discuss., in press, 2009.

Moxim, W. J. and Levy, H.: A model analysis of the tropical South Atlantic Ocean tropospheric ozone maximum: The interaction of transport and chemistry, J. Geophys. Res., 105, 17 393-17415, 2000.

Newchurch, M. J., Ayoub, M. A., Oltmans, S., Johnson, B., and Schmidlin, F. J.: Vertical distribution of ozone at four sites in the United States, J. Geophys. Res., 108, 4031, doi:10.1029/2002JD002059, 2003.

Pickering, K. E., Thompson, A. M., Wang, Y., Tao, W.-K., McNamara, D. P., Kirchhoff, V. M. J. H., Heikes, B. G., Sachse, G. W., Bradshaw, J. D., Gregory, G. L., and Blake, D. R.: Convective transport of biomass burning emissions over Brazil during TRACE A, J. Geophys. Res., 101, 23 993-24 012, 1996.

Randel, W. J., Park, M. J., Wu, F., and Livesey, N.: A large annual cycle in ozone above the tropical tropopause linked to the Brewer-Dobson circulation, J. Atmos. Sci., 64, 4479-4488, 2007.

Raut, J.-C. and Chazette, P.: Radiative budget in the presence of multi-layered aerosol structures in the framework of AMMA SOP-0, Atmos. Chem. Phys., 8, 6839-6864, 2008, http://www.atmos-chem-phys.net/8/6839/2008/.

Reed, R. and Vicek, C. L.: Annual temperature variation in lower tropical stratosphere, J. Atmos. Sci., 26, 163, 1969.

Reeves, C., Formenti, P., Ancellet, G., Borbon, A., Cairo, F., Mari, C., Methven, J., Schlager, H., and Thouret, V.: Chemical characterisation of the West Africa monsoon during AMMA, Atmos. Chem. Phys. Discuss., in preparation, 2009.

Reid, G. and Gage, K.: On the annual variation in height of the tropical tropopause, J. Atmos. Sci., 38, 1928-1938, 1981.

Saunois, M., Mari, C., Thouret, V., Cammas, J.-P., Peyrillé, P., Lafore, J.-P., Sauvage, B., Volz-Thomas, A., Nédélec, P., and Pinty, J.-P.: An idealized two-dimensional approach to study the impact of the West African monsoon on the meridional gradient of tropospheric ozone, J. Geophys. Res., 113, D07306, doi:10.1029/2007JD008707, 2008a.

Saunois, M., Thouret, V., Mari, C., Sauvage, B., and Jacob, D. J.: Ozone Enhancement over Cotonou during the Wet Season: Combined influence of Biomass Burning and Local Anthropogenic pollution, in: IGAC 10th International Conference, 2008b.

Sauvage, B., Thouret, V., Cammas, J.-P., Gheusi, F., Athier, G., and Nédélec, P.: Tropospheric ozone over Equatorial Africa: regional aspects from the MOZAIC data, Atmos. Chem. Phys., 5, 311335,2005 ,

http://www.atmos-chem-phys.net/5/311/2005/.

Sauvage, B., Thouret, V., Thompson, A., Witte, J. C., Cammas, J.P., Nédélec, P., and Athier, G.: Enhanced view of the tropical Atlantic ozone paradox and zonal wave one from the in situ MOZAIC and SHADOZ data, J. Geophys. Res., 111, D01301, doi:10.1029/2005JD006241, 2006.

Sauvage, B., Gheusi, F., Thouret, V., Cammas, J.-P., Duron, J., Escobar, J., Mari, C., Mascart, P., and Pont, V.: Medium-range mid- tropospheric transport of ozone and precursors over Africa: two numerical case studies in dry and wet seasons, Atmos. Chem. Phys., 7, 5357-5370, 2007a, http://www.atmos-chem-phys.net/7/5357/2007/.

Sauvage, B., Martin, R. V., van Donkelaar, A., Liu, X., Chance, K., Jaeglé, L., Palmer, P. I., Wu, S., and Fu, T.-M.: Remote sensed and in situ constraints on processes affecting tropical tropospheric ozone, Atmos. Chem. Phys., 7, 815-838, 2007b, http://www.atmos-chem-phys.net/7/815/2007/.

Sauvage, B., Martin, R. V., van Donkelaar, A., and Ziemke, J. R.: Quantification of the factors controlling tropical tropospheric ozone and the South Atlantic maximum, J. Geophys. Res., 112, D11309, doi:10.1029/2006JD008008, 2007c.

Sauvage, B., Thouret, V., Cammas, J.-P., Brioude, J., Nédélec, P., and Mari, C.: Meridional ozone gradients in the African upper troposphere, Geophys. Res. Lett., 34, L03817, doi:10.1029/2006GL028542, 2007d.

Schoeberl, M., Ziemke, J., Bojkov, B., et al.: A trajectorybased estimate of the tropospheric ozone column using the residual method, J. Geophys. Res., 112, D24549, doi:10.1029/2007JD008773, 2007.

Serça, D., Delmas, R., Le Roux, X., Parsons, D. A. B., Scholes, M. C., Abbadie, L., Lensi, R., Ronce, O., and Labroue, L.: Comparison of nitrogen monoxide emissions from several African tropical ecosystems and influence of season and fire, Global Biogeochem. Cy., 12(4), 637-651, 1998.

Smit, H. G. J., Straeter, W., Johnson, B. J., et al.: Assessment of the performance of ECC-ozonesondes underquasi-flight conditions in the environmental simulation chamber: Insights fromthe Jülich Ozone Sonde Intercomparison Experiment (JOSIE), J. Geophys. Res., 112, D19306, doi:10.1029/2006JD007308, 2007.

Smyth, S. B., Standholm, S. T., Bradshaw, J. D., et al.: Factors influencing the upper free tropospheric distribution of reactive nitrogen over the South Atlantic during the TRACE A experiment, J. Geophys. Res., 101(D19), 24 165-24 186, 1996.

Swap, R., Suttles, J., King, M., Platnick, S., Privette, J., and Scholes, R.: Africa burning: A thematic analysis of the Southern African Regional Science Initiative (SAFARI 2000), J. Geophys. Res., 108(D13), 8465, doi:10.1029/2002JD002762, 2003.

Thompson, A. M., Doddridge, B. G., Witte, J. C., Hudson, R. D., Luke, W. T., Johnston, J. E., Johnston, B. J., Oltmans, S. J., and Weller, R.: A tropical Atlantic paradox: Shipboard and satellite views of a tropospheric ozone maximum and wave-one in January-February 1999, Geophys. Res. Lett., 27, 3317-3320, 2000.

Thompson, A. M., Witte, J. C., McPeters, R. D., et al.: Southern Hemisphere Additional Ozonesondes (SHADOZ) 1998-2000 tropical ozone climatology 1. Comparison with Total Ozone Mapping Spectrometer (TOMS) and ground-based measurements, J. Geophys. Res., 108, 8238, doi:10.1029/2001JD000967, 2003a.

Thompson, A. M., Witte, J. C., Oltmans, S. J., et al.: Southern Hemisphere Additional Ozonesondes (SHADOZ) 19982000 tropical ozone climatology 2. Tropospheric variability and the zonal wave-one, J. Geophys. Res., 108, 8241, doi:10.1029/2002JD002241, 2003b.

Thompson, A. M., Witte, J. C., Smit, H. G. J., et al.: Southern Hemisphere Additional Ozonesondes (SHADOZ) 1998-2004 tropical ozone climatology 3. Instrumentation, station variability, 
evaluation with simulated flight profiles, J. Geophys. Res., 112, D03304, doi:10.1029/2005JD007042, 2007.

Thouret, V., Marenco, A., Logan, J., Nédélec, P., and Grouhel, C.: Comparisons of ozone measurements from the MOZAIC airborne program and the ozone sounding network at eight locations, J. Geophys. Res., 103(D14), 25 695-25 720, 1998.

van der Werf, G. R., Randerson, J. T., Giglio, L., Collatz, G. J., Kasibhatla, P. S., and Arellano Jr., A. F.: Interannual variability in global biomass burning emissions from 1997 to 2004, Atmos. Chem. Phys., 6, 3423-3441, 2006,

http://www.atmos-chem-phys.net/6/3423/2006/.

Williams, J. E., Scheele, M. P., van Velthoven, P. F. J., Cammas, J.-P., Thouret, V., Galy-Lacaux, C., and Volz-Thomas, A.: The influence of biogenic emissions from Africa on tropical tropospheric ozone during 2006: a global modeling study, Atmos. Chem. Phys. Discuss., 9, 10367-10427, 2009a,

http://www.atmos-chem-phys-discuss.net/9/10367/2009/.
Williams, J., Bouarar, I., Josse, B., et al.: Global Chemistry simulations in the AMMA-Model Intercomparison project, B. Am. Meteorol. Soc., under revision, 2009b.

Ziemke, J., Chandra, S., Duncan, B., Froidevaux, L., Bhartia, P., Levelt, P., and Waters, J.: Tropospheric ozone determined from aura OMI and MLS: Evaluation of measurements and comparison with the Global Modeling Initiative's Chemical Transport Model, J. Geophys. Res., 111, D19303, doi:10.1029/2006JD007089, 2006. 